
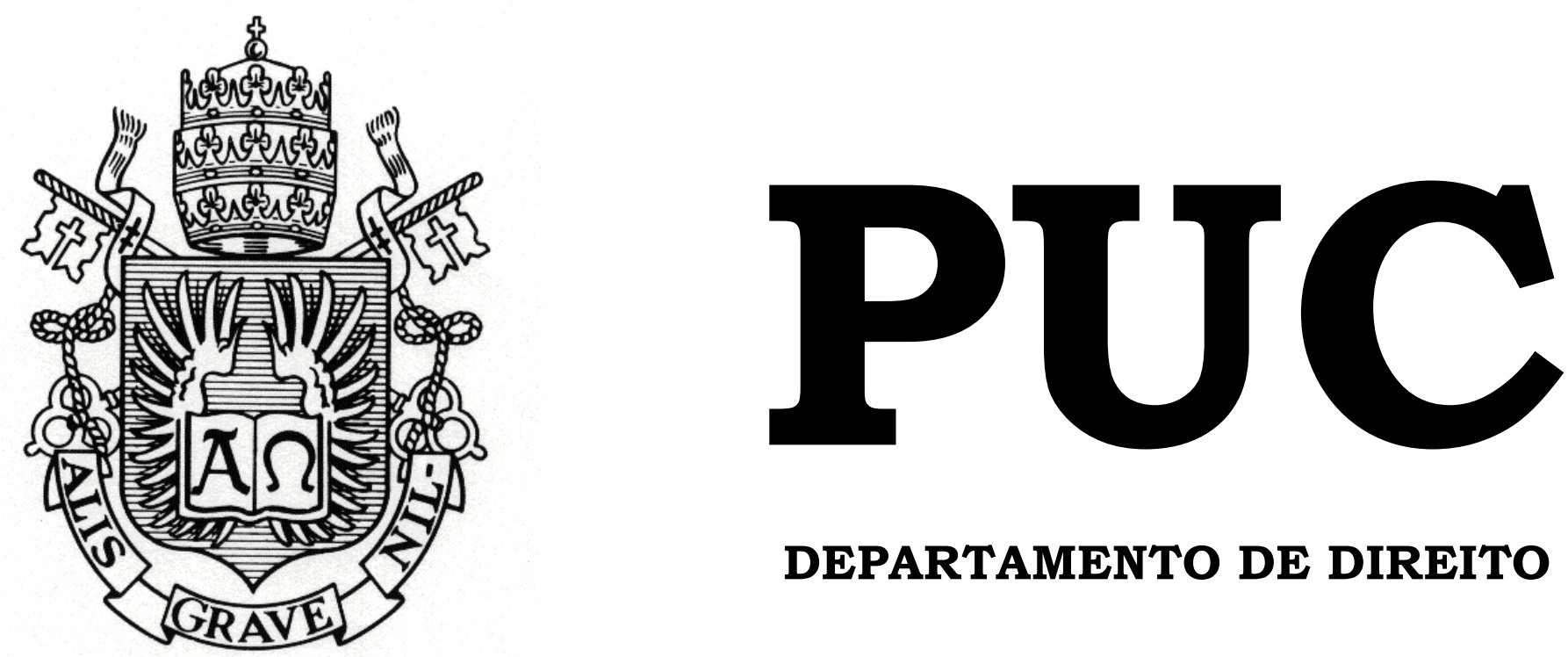

DEPARTAMENTO DE DIREITO

\title{
O CONCEITO DE CRÉDITO IMOBILIÁRIO E A SUA RELEVÂNCIA PARA O MERCADO DE SECURITIZAÇÃO
}

por

VITOR DE ANDRADE SZMARAGD

ORIENTADOR: FRANCISCO ANTUNES MACIEL MÜSSNICH 2017.2

PONTIFÍCIA UNIVERSIDADE CATÓLICA DO RIO DE JANEIRO RUA MARQUÊS DE SÃO VICENTE, 225 - CEP 22453-900 RIO DE JANEIRO - BRASIL 


\title{
O CONCEITO DE CRÉDITO IMOBILIÁRIO E A SUA RELEVÂNCIA PARA O MERCADO DE SECURITIZAÇÃO
}

\author{
por \\ VITOR DE ANDRADE SZMARAGD
}

Monografia

apresentada

ao

Departamento de Direito da Pontifícia Universidade Católica do Rio de Janeiro (PUC-Rio) para a obtenção do Título de Bacharel em Direito.

Orientador(a): Francisco

Antunes Maciel Müssnich. 
Dedicatória

Não poderia haver outra forma de iniciar esta monografia senão dedicando-a, com muito amor e carinho, às três pessoas mais importantes da minha vida: meu pai, minha mãe e minha irmã. Agradeço não apenas pelo incentivo e pelo suporte durante esses cinco anos de graduação, mas, sobretudo, por me passarem valores tão corretos e tão especiais desde o dia em que nasci. 


\section{Agradecimentos}

Pedindo perdão pela redundância, gostaria de iniciar este capítulo de agradecimentos para reiterar a minha gratidão incondicional à minha família, sem a qual não seria possível, de forma alguma, estar concluindo a minha graduação.

Ao meu pai, Marcos, agradeço não apenas por ter me ensinado os caminhos certos - como o do Botafogo -, mas por sempre confiar e sempre esperar o melhor de mim. Tenho o sonho de ser um profissional tão competente e bem sucedido quanto você.

À minha mãe, Eneida, por ser tão dedicada e estar ao meu lado em todos os momentos importantes da minha vida, os bons e os ruins. Você me dá forças para sempre seguir em frente.

À Natália, ao Rafael e - agora - ao Antônio, por completarem e darem continuidade a essa família incrível. A união de vocês é artigo raro e muito inspirador.

Além da minha família, gostaria de agradecer aos meus colegas do Bocater, Camargo, Costa e Silva, Rodrigues Advogados Associados, escritório de excelência em que tive a honra e o prazer de estagiar durante quase dois anos. Sem pretender cometer injustiças, faço um agradecimento especial ao Fábio e ao Maurício, chefes que me acompanham de perto e me transmitem, diariamente, sempre com muito zelo, ensinamentos fundamentais para o meu crescimento jurídico e profissional.

No mesmo sentido, agradeço ao meu orientador, Chico Müssnich, por todos os ensinamentos passados ao longo dos anos, não apenas no âmbito desta monografia. Foi um privilégio tê-lo como professor e 
orientador durante essa graduação.

Por fim, agradeço imensamente a todas as amizades preciosas que construí durante esses cinco anos de universidade, especialmente aqueles que têm estado ao meu lado desde 2013, do início ao fim. Tenho muito orgulho ter formado amigos tão íntegros, afetuosos, inteligentes e capacitados. Sem dúvidas, a caminhada foi muito mais construtiva e prazerosa ao lado de todos vocês.

Obrigado! 


\section{Resumo}

Monografia apresentada ao Departamento de Direito da Pontifícia Universidade Católica do Rio de Janeiro como requisito parcial à obtenção do título de Bacharel em Direito. O referido trabalho de conclusão de curso possui o objetivo de examinar, debater e criticar o conceito de crédito imobiliário no âmbito do ordenamento jurídico brasileiro, enfatizando-se a sua relevância prática para o mercado de securitização e para a disciplina da Lei $n^{\circ} 9.514 / 1997$. Essa tarefa será realizada, didaticamente, a partir das seguintes etapas: (i) organização e exposição da legislação vigente; (ii) análise e crítica do material doutrinário disponível; (iii) sistematização dos precedentes da Comissão de Valores Mobiliários e a elaboração de uma crítica ao seu posicionamento atual; e (iv) a proposta de uma tese jurídica mais adequada à caracterização dos créditos imobiliários. Em síntese, este trabalho consiste em explicitar a realidade teórica e prática do crédito imobiliário e, com base nesse conhecimento, sugerir um conjunto de requisitos considerados mais adequados à sua conceituação.

Palavras-chave: Direito Societário. Direito Imobiliário. Crédito Imobiliário. Conceito. Securitização. Lei 9.514/1997. CCI. CRI. Mercado de Capitais. Financiamento Imobiliário. Comissão de Valores Mobiliários. 


\section{Sumário}

\section{Lista de siglas e abreviações utilizadas}

Introdução

1. Preliminarmente 11

1.1. Uma breve contextualização 11

1.2. Cédula de Crédito Imobiliário (CCI) 13

1.3. Certificado de Recebíveis Imobiliários (CRI) 16

2. $\mathrm{O}$ conceito de crédito imobiliário 20

2.1. Legislação 20

2.2. Doutrina 24

2.2.1. Melhim Namem Chalhub 25

2.2.2. Ricardo Pereira Lira 27

2.2.3. Arthur Rios Jr. 30

2.2.4. Ivo Waisberg e Herbert Morgenstern Kugler 32

2.2.5. Gladston Mamede 33

2.2.6. Conclusão

3. Precedentes e Atuação Reguladora 37

3.1. Processo Administrativo CVM n RJ2001/1981 ("Caso

WT Administradora") 37

3.2. Processo Administrativo CVM n RJ2002/3032 ("Caso CIBRASEC") 39

3.3. Processo Administrativo CVM n RJ2003/5639 ("Caso Maxpower") 41

3.4. Processos Administrativos CVM n ${ }^{\circ} \mathrm{s}$ RJ2006/6950 e RJ2007/0547 (“Caso Rio Bravo”) 44 
3.5. Processo Administrativo CVM n 2012/12177 ("Caso $\begin{array}{ll}\text { Rede D'Or) } & 47\end{array}$

3.5.1. A descrição do caso 47

3.5.2. A mudança do entendimento da área técnica e a utilização implícita do critério da destinação

3.5.3. A chegada do processo ao Colegiado e o surgimento de um novo critério: o do fluxo de pagamento 50

3.5.4. E o critério da origem? 50

3.5.5. A conclusão do caso 52

3.6. Processo Administrativo CVM no 19957.009618/2016-30

(“Caso RB Capital”) 53

3.6.1. A descrição do caso

3.6.2. A decisão do Colegiado 54

3.6.3. Conclusão 56

3.7. Conclusão 57

4. Uma análise crítica do posicionamento atual da CVM e a proposta de uma interpretação diversa. 59

4.1. Os aspectos positivos do entendimento atual da Autarquia 59

4.2. O outro lado da moeda: a inadequação do critério do fluxo de pagamento. 62

4.3. Ajustes pertinentes à interpretação atual do Colegiado: a propositura de um novo modelo. $\quad 65$

$\begin{array}{ll}\text { 5. Conclusão } & 67\end{array}$

$\begin{array}{ll}\text { Bibliografia } & 70\end{array}$ 


\section{Lista de siglas e abreviações utilizadas}

"ABRASCA" - Associação Brasileira das Companhias Abertas;

"ANBIMA" - Associação Brasileira das Entidades dos Mercados Financeiro e de Capitais;

"ANDIMA" - Associação Nacional das Instituições do Mercado Financeiro;

"BACEN" - Banco Central do Brasil;

"CETIP" - Central de Custódia e de Liquidação Financeira de Títulos (CETIP S.A. - Mercados Organizados);

"CCI" - Cédula de Crédito Imobiliário;

"CMN" - Conselho Monetário Nacional;

"Colegiado" - Órgão Colegiado da Comissão de Valores Mobiliários

"CRI" - Certificado de Recebíveis Imobiliário;

"CRSFN" - Conselho de Recursos do Sistema Financeiro Nacional;

"CVM" ou "Autarquia" - Comissão de Valores Mobiliários;

"Lei 9.514/1997" - Lei no 9.514, de 20 de novembro de 1997.

"LIG" - Letra Imobiliária Garantida;

"LSA" - Lei 6.404/64;

"PFE" ou "PFE-CVM" - Procuradoria Federal Especializada da Comissão de Valores Mobiliários;

"PJU" ou "PJU-CVM" - Procuradoria Jurídica da Comissão de Valores Mobiliários;

"SFI" - Sistema de Financiamento Imobiliário;

"SRE" - Superintendência de Registro de Valores Mobiliários da Comissão de Valores Mobiliários 


\section{Introdução}

Um dos maiores desafios de se fazer uma abordagem conceitual é conseguir demonstrar a relevância prática daquilo que se pretende abordar. Afinal, é preciso ser franco: temas puramente conceituais tendem a ser monótonos, cansativos e, em alguns casos, até mesmo desestimulantes para a maioria dos leitores, por mais atentos e interessados que estes possam ser.

É essa a reação que se buscará evitar ao longo do presente trabalho. Embora seu objetivo central seja a discussão de um conceito - isto é, o de "crédito imobiliário" -, a primeira coisa que deve ser enfatizada, antes de mais nada, é a existência de implicações práticas distintas que podem resultar dessa discussão, especialmente no que diz respeito ao mercado de securitização de recebíveis imobiliários e à organização de operações estruturadas.

Com efeito, um dos eventos que mais motivou a elaboração deste trabalho jurídico foi a oportunidade de ter participado, junto aos colegas de escritório, de uma operação estruturada de financiamento, na qual, diante da omissão legislativa, os advogados e estruturadores envolvidos não souberam precisar se os recebíveis imobiliários decorrentes de um contrato de compra e venda de apartamentos poderiam, ou não, ser considerados créditos imobiliários para os fins da legislação e da jurisprudência. No caso concreto, a eventual impossibilidade de enquadramento desses recebíveis no conceito de crédito imobiliário impediria a constituição de uma série de CCIs (que serviriam de lastro para um CRI) e, ao final de tudo, inviabilizaria toda a operação estruturada que se pretendia fazer para financiar a construção de um resort.

Embora ainda seja um pouco cedo para citar autores, não há como falar da relevância prática do conceito de crédito imobiliário sem aludir às conscientes e objetivas palavras do advogado Arthur Rios Jr., in verbis: "Inexiste definição legal sobre o que seriam créditos imobiliários. A 
doutrina, por sua vez, pouco se preocupou com a questão. A compreensão de um conceito de crédito imobiliário, compatível com a Lei no 9.517/95, é relevante, pois somente este pode lastrear CRIs. Logo, créditos de natureza diversa não poderão ser securitizados com base nas regras da citada lei." "I

Nesse ínterim, nota-se que a forma de se compreender o conceito de crédito imobiliário possui o condão de definir, por si só, a viabilidade de uma operação de grande porte, basicamente determinando se milhões de reais poderão ser movimentados na realização de empreendimentos relevantes para o desenvolvimento e manutenção da economia nacional. Causa perplexidade que, diante de tal importância, a legislação e a doutrina tenham sido tão desinteressadas em fixar critérios claros para a delimitação do conceito, sendo esse, justamente, mais um grande fator que motivou a escolha do tema e a elaboração do presente trabalho.

Tendo tudo isso em vista, o trabalho percorrerá o conceito de crédito imobiliário desde seu aspecto teórico, segundo a legislação e a doutrina, até o seu aspecto prático, com a análise dos precedentes e casos concretos que foram consolidando o entendimento atual da CVM. Ao final, a parte mais relevante: uma crítica direta ao entendimento atual da Autarquia, propondose, então, um conjunto de regras e critérios distintos, o qual caracterizaria mais adequadamente o conceito de crédito imobiliário no melhor interesse do mercado e da economia.

Dessa forma, o objetivo é que esse trabalho possua uma função não apenas analítica, mas, ainda, de proposição, tecendo críticas, fazendo sugestões e contribuindo ativamente para uma evolução conceitual que possa sanar as obscuridades da lei e conferir uma maior segurança jurídica aos agentes do mercado imobiliário.

\footnotetext{
${ }^{1}$ RIOS JUNIOR, Arthur. Securitização de Créditos Imobiliários. Revista Magister de Direito
} 


\section{Preliminarmente}

\subsection{Uma breve contextualização}

Como já mencionado na introdução acima, a metodologia inicial deste trabalho consiste em abordar o conceito de crédito imobiliário sob a ótica da legislação, da doutrina e da jurisprudência, percorrendo aquilo consensualmente se entende como os três pilares fundamentais de um bom direito.

Entretanto, não seria confortável - e tampouco adequado - adentrar em tais exposições sem realizar, preliminarmente, uma breve contextualização a respeito dos principais termos e institutos jurídicos que estarão presentes ao longo de todo o desenvolvimento da tese. Afinal, como já foi oportunamente justificado, o objetivo do trabalho não é a análise pura e isolada de um conceito, tão somente para fins teóricos, mas, na realidade, sua compreensão diante do funcionamento prático do mercado imobiliário brasileiro.

Pois bem. Sem pretender entrar no mérito do conceito propriamente dito, pode-se afirmar que o crédito imobiliário possui duas formas distintas de existir e de se comportar juridicamente. De um lado, têm-se os créditos imobiliários que possuem um fim em si mesmo, constituindo-se, pura e simplesmente, como a representação de uma dívida contraída entre devedor e credor, sejam quais forem os critérios utilizados para caracterizar tal crédito como imobiliário. Nesses casos, o ciclo de vida do crédito é ser constituído, produzir os efeitos jurídicos respectivos e, uma vez quitado, ser extinto, sem maiores implicações. Seria o caso de um crédito que resultasse de um contrato de compra e venda de um determinado imóvel, por exemplo.

De outro lado, têm-se os créditos imobiliários que, após serem constituídos como a representação de uma dívida de caráter imobiliário, 
serão utilizados como lastro de instrumentos de natureza e de características diversas, tais como a Cédula de Crédito Imobiliário (CCI) ou o Certificado de Recebíveis Imobiliários (CRI). Nessa segunda hipótese, o crédito não existe per se, mas sim como um lastro para a constituição de outros instrumentos e para a consecução das mais diversas finalidades mercantis, a exemplo da ampliação da circulabilidade dos créditos.

Na prática, é forçoso reconhecer que as negociações de CCI e de CRI representam a parcela mais relevante do mercado imobiliário, especialmente se considerado o volume de capital que esses títulos costumam movimentar. Segundo estudo realizado pela $\mathrm{ANBIMA}^{2}$, as emissões de CRI foram responsáveis pela movimentação de $\mathrm{R} \$ 17.649 .000 .000,00$ (dezessete bilhões e seiscentos e quarenta e nove milhões de reais) apenas no ano de 2016. Nesse mesmo ano, no dia 30.12.2016, a CETIP chegou a estocar o volume significativo de $\mathrm{R} \$ 73.630 .552 .417,06$ (setenta e três bilhões, seiscentos e trinta milhões, quinhentos e cinquenta e dois mil, quatrocentos e dezessete reais e seis centavos) em CRIs ${ }^{3}$. Evidentemente, não há como comparar a o impacto de tais números com o de relações menos complexas, geralmente de cunho doméstico e enquadradas na primeira forma de existência dos créditos imobiliários prevista na classificação supra.

Por isso, é de fundamental importância que esses conceitos fiquem claros logo de início, até porque a análise da legislação, da doutrina e principalmente - da jurisprudência relativas ao assunto exige uma compreensão prévia e consistente do mercado imobiliário e de seus institutos jurídicos mais relevantes, dentre os quais se incluem, por óbvio,

\footnotetext{
${ }^{2}$ ASSOCIAÇÃO BRASILEIRA DAS ENTIDADES DOS MERCADOS FINANCEIRO E DE CAPITAIS. CRI: Consolidado Mensal (N). Disponível em: <http://www.anbima.com.br/pt_br/informar/estatisticas/mercado-de-capitais/cri-consolidadomensal-n.htm>. Acesso em 06.07.2017.

${ }^{3}$ CENTRAL DE CUSTÓDIA E DE LIQUIDAÇÃO FINANCEIRA DE TÍTULOS - CETIP. CRI - Certificado de Recebíveis Imobiliários: estoque. Disponível em: 〈http://estatisticas.cetip.com.br/astec/series_v05/paginas/web_v04_10_03_consulta.asp〉. Acesso em 06.07.2017..
} 
instrumentos como a CCI e o CRI. Vamos a eles.

\subsection{Cédula de Crédito Imobiliário (CCl)}

Disciplinada pela Lei 10.931/2004, a CCI nada mais é do que uma cédula que representa um crédito imobiliário. Por mais simples e resumida que tal definição possa parecer, é exatamente nesses termos que reza o artigo 18 da referida lei, abaixo transcrito:

Art. 18. É instituída a Cédula de Crédito Imobiliário - CCI para representar créditos imobiliários.

Com efeito, a CCI é um documento representativo que transforma o crédito imobiliário de origem em um título circulável, contendo, em seu corpo, determinadas informações a respeito do instrumento que originou o crédito que se pretende representar. Importante observar que o art. 19 da Lei 10.931/2004 determina diversas informações que devem, obrigatoriamente, constar da cédula, como a qualificação do devedor e do credor, o valor do crédito, a data de vencimento, dentre outros.

Dessa forma, a CCI possui a função de transformar um extenso contrato de financiamento, por exemplo, em um simples título de apenas uma página, otimizando muito significativamente a capacidade de circulação do crédito. Ao agilizar a sua negociação, a existência das CCIs e também dos CRIs, como se verá mais à frente - atende aos interesses mais basilares do mercado, na medida em que permite a cessão do crédito mediante endosso apostado no próprio corpo do título, sem necessidade de formalização de um contrato específico para cada cessão que se for realizar.

Além disso, outra grande vantagem é que, diferentemente do que ocorre na cessão de crédito ordinária, a CCI não exige que o devedor seja notificado a respeito de eventual cessão do crédito que ela representa. Embora muito se afirme que a CCI possui o diferencial de permitir a cessão 
do crédito independentemente da autorização do devedor, é necessário, data vênia, discordar de tal entendimento, uma vez que a regra disposta no Código Civil é justamente que a cessão de crédito independe da autorização do devedor, exigindo-se tão somente a sua notificação. Dessa forma, tal característica não representa uma verdadeira inovação da CCI em relação às formas ordinárias de cessão de um crédito. $\mathrm{O}$ correto seria afirmar que o diferencial é a desnecessidade de notificação, e não de autorização.

Por força do art. 20 da Lei 10.931/2004, a CCI qualifica-se como título executivo extrajudicial, devendo ser exigida, portanto, por meio de ação de execução a ser ajuizada após o seu vencimento. Nesse sentido, questão relevante que se coloca é saber qual seria a natureza jurídica de uma CCI, mais especificamente se ela pode, ou não, ser considerada um título de crédito para fins de aplicação das regras próprias do direito cambiário. Assim como o conceito de crédito imobiliário, a definição da natureza jurídica da CCI representa mais um desses assuntos conceituais que possuem implicações práticas de extrema relevância, razão pela qual se solicita a devida vênia para a exposição de algumas considerações sobre o tema.

Diante do completo silêncio da legislação acerca da natureza jurídica do título, alguns poucos doutrinadores e estudiosos aventuraram-se para defender ou criticar uma eventual classificação da CCI como título de crédito. Dentre os que não concordam com tal conceituação, é indispensável destacar a figura ilustre de Mamede Gladston, o qual lista dois principais motivos pelos quais a CCI não poderia ser considerada um verdadeiro título de crédito: (1) a existência de uma forma escritural do título (art. $18, \S 3^{\circ}$, da Lei 10.931/2004), o que feriria o princípio da cartularidade dos títulos de crédito; e (2) o fato de o pagamento da dívida não ser demonstrado por anotação no título ou por sua entrega ao devedor. Vejam-se as palavras do ilustre professor:

...há elementos ainda mais fortes que apontam para a necessidade de se 
reconhecer a cédula de crédito imobiliário como um título de crédito impróprio ou, se preferirem, um título de crédito imperfeito ou até título de crédito sui generis. Isso determina afirmar que não está submetida ao regime do Direito Cambiário. Em primeiro lugar, está o problema da cartularidade, que se coloca em dois planos: inicialmente, a possibilidade de emissão escritural do título, sem a correspondente cártula, ou seja, sem base material.

$[\ldots]$

Os financiamentos imobiliários, contudo, são pagos de outra forma; via de regra, por boletos, ou, mesmo, débito automático em conta. Fica claro, portanto, que o regulamento e a prática das cédulas de crédito imobiliário, com pagamentos comprováveis por todos os meios admitidos em direito, como estabelece a própria Lei 10.931/04, é incompatível com a figura do endosso e, principalmente, com as consequências jurídicas dele advindas, como o direito do credor-endossatário ao crédito anotado na cártula pela simples apresentação no título no qual esteja registrada a assinatura do endossante ou dos endossantes, considerando, em abstrato, a figura da sequência de endossos. ${ }^{4}$

Outros nomes, em sentido contrário, defendem que o princípio da cartularidade deveria ser objeto de uma modernização, de modo a admitir, em sua essência, também os títulos que sejam emitidos em forma escritural. De acordo com esses autores, o conceito de cartularidade deveria ser expandido para o conceito de "documentabilidade", contemplando as formas de representação eletrônicas ou por meio de certificado. Nessa hipótese, as CCIs poderiam ser qualificadas como um título de crédito, ainda que emitidas em forma escritural. É a posição adotada pelo professor e advogado Jean Carlos Fernandes, ao afirmar que "o princípio da documentabilidade, extensivo a todos os títulos, melhor se aperfeiçoa aos títulos de crédito escriturais, em nada prejudicando os títulos cartulares. "5

Diante de toda essa controvérsia e com todo o respeito devido aos autores mencionados, a resposta que melhor parece se adequar à pergunta formulada é: depende. Se a CCI for emitida em sua forma cartular e for quitada mediante sua apresentação ao devedor, não há nada que possa

\footnotetext{
${ }^{4}$ MAMEDE, Gladston. Letra de Crédito Imobiliário e Cédula de Crédito Imobiliário Segundo a Lei 10.931, de 02 de Agosto de 2004. Revista Magister de Direito Empresarial, Concorrencial e do Consumidor, Porto Alegre, $\mathrm{n}^{\circ}$ 01, p. 59, fev./mar., 2005.

${ }^{5}$ FERNANDES, Jean Carlos: A definição de títulos de crédito e a readequação de seus princípios na contemporaneidade. Disponível em: <http://www.cartaforense.com.br/conteudo/artigos/adefinicao-de-titulos-de-credito-e-e-readequacao-de-seus-principios--na contemporaneidade/10162>. Acesso em 04.11.2017.
} 
diferenciar esse título de um verdadeiro título de crédito, razão pela qual, nesses casos, deve-se proceder à sua devida caracterização. Entretanto, se a CCI for emitida em forma escritural e for quitada de formas outras senão mediante a apresentação do título e a anotação da respectiva quitação, o pressupostos do título de crédito não restarão atendidos e, portanto, as regras próprias do direito cambiário não possuirão aplicação, visto não se tratar de um título de crédito em sua essência. A pluralidade de possibilidades aberta pela Lei 10.931/2004 deve resultar, naturalmente, em uma pluralidade de possíveis conceituações.

\subsection{Certificado de Recebíveis Imobiliários (CRI)}

Tal qual a CCI, o CRI é um título que se origina a partir de um crédito imobiliário, sendo responsável, igualmente, pela ampliação de sua capacidade de circulação e negociação no mercado. De acordo com o art. $6^{\circ}$ da Lei 9.514/1997, que institui o Sistema Financeiro Imobiliário (SFI) e trata de outros temas relevantes, o CRI é um "título de crédito nominativo, de livre negociação, lastreado em créditos imobiliários e constitui promessa de pagamento em dinheiro "6.

Embora tal redação sugira grande semelhança entre o CRI e a CCI, é necessário ter em conta que esses títulos possuem mais diferenças do que semelhanças. Em primeiro lugar, porque o CRI não é um mero instrumento de representação e reprodução de um crédito imobiliário, como é o caso da CCI, mas sim um título de crédito gerado por uma atividade de securitização, a qual, em sua essência, é responsável pela transformação de créditos imobiliários em títulos padronizados e negociáveis no mercado de capitais. Na definição clara e objetiva do Securitization Standing Committee, da agência de classificação de risco Moody's Investors Service, "securitização é o processo meio do qual uma variedade de ativos

\footnotetext{
${ }^{6}$ Art. 6, caput, da Lei 9.514/1997.
} 
financeiros e não financeiros são agrupados em títulos e vendidos a investidores". 7

É exatamente isso o que acontece com o CRI. Por meio do processo de securitização, um crédito imobiliário - que pode estar em sua forma primária ou representado por uma CCI - é utilizado como lastro para a criação de um ou mais títulos padronizados, os quais podem ser adquiridos tanto em operações previamente estruturadas quanto mediante o seu oferecimento no mercado secundário. Seja qual foi a maneira, o CRI negociado representa uma promessa de pagamento, de modo que, em regra, o comprador o adquire como uma forma de investimento, pagando um valor único no momento de sua aquisição e se tornando titular dos créditos que lastreiam o título. Por óbvio, o valor que o investidor paga pelo título muitas vezes à vista - é menor do que o somatório que ele vai receber pelos créditos no final do circuito, em seu vencimento final. Assim como um banco faz jus ao chamado spread bancário, o investidor de um CRI também faz jus à remuneração do capital adiantado ao tomador no momento da aquisição do título.

Dessa forma, o processo de securitização é capaz de atender tanto aos interesses do tomador, que obtém recursos de forma imediata, sem precisar esperar a realização de todos os seus direitos creditórios ao longo do tempo, quanto do investidor, que oferece os seus recursos disponíveis em contrapartida a um ganho de capital futuro. Vejam-se as preciosas lições de Melhim Namem Chalhub a esse respeito:

A securitização propicia, fundamentalmente, do ponto de vista do tomador de recursos, o acesso a uma fonte alternativa de financiamento, com redução de custos, seja por via direta, mediante diminuição da taxa de juros, ou por via indireta, com o encurtamento dos prazos de retorno de ativos imobilizados, por

\footnotetext{
${ }^{7}$ Tradução livre da seguinte redação original: "Securitization is the process through which a variety of financial and non-financial assets are packaged into securities that are then sold to investors." (SECURITIZATION STANDING COMITEE; SANBACK, Annika. Desmystifying Securitization for Unsecured Investors. Disponível em: < https://www.moodys.com/sites/products/AboutMoodysRatingsAttachments/2001700000415918.p df.>. Acesso em 06.11.2017).
} 
meio de títulos de dívida, e, do ponto de vista do investidor, pode viabilizar o objetivo de dispor de uma modalidade de investimento que pode oferecer vantagens, comparativamente com outros papéis do mercado, em razão da maior rentabilidade e maior segurança, pois a redução de riscos, ou sua relativa eliminação, é um dos propósitos fundamentais do processo de securitização. ${ }^{8}$

É operação vantajosa para o titular dos créditos, pois, ao cedê-los, obterá a antecipação de receita que viabiliza o financiamento da sua atividade produtiva, presumivelmente a custo reduzido, na medida em que se trata de desintermediação financeira; é igualmente vantajoso para o investidor pela segurança que oferece, pois os títulos são emitidos com lastro em créditos cujo produto é destinado ao resgate do investimento. ${ }^{9}$

Considerando a possibilidade de sua negociação diretamente no mercado de capitais, é fundamental ressaltar que o CRI possui natureza de valor mobiliário para os efeitos do art. $2^{\circ}$, III, da Lei 6.385/1976, conforme determinado pela Resolução no 2517 do Conselho Monetário Nacional, de 29 de junho de $1998^{10}$. Além de representar mais uma importante diferença em relação à CCI - a qual, como visto, é título executivo extrajudicial -, a qualificação do CRI como valor mobiliário permite que esse título seja negociado da mesma forma e com a mesma facilidade de uma ação na bolsa de valores, por exemplo. Trata-se do avanço máximo proporcionado pela atividade de securitização.

Por fim, é fundamental ressaltar que, enquanto valor mobiliário resultante de uma atividade de securitização, o CRI é um título de emissão privativa das companhias securitizadoras, conforme enunciado pelo art. $6^{\circ}$, parágrafo único, da Lei 9.514/1997. Eis aqui mais uma diferença desse título em relação à CCI, que pode ser emitida livremente por quem quer que seja o titular dos créditos, não se exigindo qualificação especial. No caso do CRI, a revés, o titular cede os créditos imobiliários à companhia

\footnotetext{
${ }^{8}$ CHALHUB, Melhim Namem. Negócio Fiduciário. $4^{\mathrm{a}}$ edição. Rio de Janeiro: Editora Renovar, 2009. p. 371.

${ }^{9}$ Id., Alienação Fiduciária, Incorporação Imobiliária e Mercado de Capitais: Estudos e Pareceres. $1^{a}$ Edição. Rio de Janeiro: Editora Renovar, 2012. p. 490.

${ }^{10}$ De acordo com o art. 41 da Lei 9.514/1997, o Conselho Monetário Nacional possui competência para regulamentar as disposições da referida lei, razão pela qual, nesse caso, as resoluções administrativas do CMN possuem efeitos vinculantes.
} 
securitizadora e esta, na condição formal de titular, emite o título e o negocia no mercado.

Diante da síntese exposta acima, pode-se afirmar que o CRI simboliza um passo ainda maior em prol da circulabilidade e da movimentação do capital imobiliário, uma vez que ele não apenas facilita a cessão dos créditos, mediante a constituição de um título, como permite, ainda, a negociação desses créditos em um mercado aberto de maior alcance. 


\section{2. $O$ conceito de crédito imobiliário}

Realizada uma breve contextualização a respeito do funcionamento do mercado imobiliário e dos principais conceitos que serão utilizados à frente, passa-se, então, à análise direta e objetiva do que vem a ser um crédito imobiliário. Conforme já salientado na introdução, tal análise será dividida em três capítulos - legislação, doutrina e jurisprudência. É o que se verá a partir de agora.

\subsection{Legislação}

Não poderia haver outra forma de iniciar a presente abordagem senão reforçando o seguinte fato: a legislação brasileira não define o que vem a ser um crédito imobiliário. A compreensão de tal assertiva é de fundamental importância não apenas para a contextualização deste capítulo, mas, na realidade, para todo o teor do presente trabalho, que em grande parte se justifica pela insegurança jurídica proporcionada pela omissão legislativa na definição do conceito.

Com efeito, existem inúmeras leis que disciplinam temas intimamente relacionados ao crédito imobiliário, direta ou indiretamente, sem que qualquer uma delas tenha sequer dado uma pista ao aplicador do Direito no que se refere à forma adequada de conceituação. Dentre todas, merecem destaque as já abordadas Leis 10.931/2004 e 9.514/1997 e, ainda, a Lei $4.380 / 1964^{11}$, todas se utilizando repetidamente do termo "crédito imobiliário" como se este fosse um termo contratual definido que não demandasse a sua devida conceituação. Apenas a título de exemplo, vejamse algumas passagens retiradas das leis supramencionadas:

\footnotetext{
11 "Institui a correção monetária nos contratos imobiliários de interêsse social, o sistema financeiro para aquisição da casa própria, cria o Banco Nacional da Habitação (BNH), $e$ Sociedades de Crédito Imobiliário, as Letras Imobiliárias, o Serviço Federal de Habitação e Urbanismo e dá outras providências."
} 
É instituída a Cédula de Crédito Imobiliário - CCI para representar créditos imobiliários. (Art. 18 da Lei 10.931/2004)

A securitização de créditos imobiliários é a operação pela qual tais créditos são expressamente vinculados à emissão de uma série de títulos de crédito, mediante Termo de Securitização de Créditos, lavrado por uma companhia securitizadora, do qual constarão os seguintes elementos: (Art. $8^{\circ}$ da Lei 9.514/1997)

Situação bastante similar ocorre em relação aos atos normativos infralegais, entendidos, no ordenamento jurídico brasileiro, como as resoluções, as instruções, as portarias e todos os demais atos administrativos que tenham o objetivo de regulamentar uma lei primária. Historicamente, todos os normativos vinham seguindo o exemplo das leis primárias e sendo igualmente omissos quanto à conceituação do crédito imobiliário, fato que pode ser observado, a título de exemplo, nas Resoluções $\mathrm{n}^{\mathrm{o}} 3.347 / 2006^{12}, 4.292 / 2013^{13}$ e $2.517 / 1998$ do BACEN e na Instrução CVM no $414 / 2004^{14}$. Vejam-se as seguintes passagens:

A operação de crédito imobiliário do Sistema Financeiro da Habitação (SFH) que vier a ser objeto de portabilidade permanecerá nessa condição, inclusive para fins de verificação do atendimento da exigibilidade de aplicação dos recursos captados em depósitos de poupança, devendo observar as disposições legais e regulamentares relativas ao $\mathrm{SFH}$, exceto o limite máximo do valor de avaliação do imóvel. (Art. 11, parágrafo único, da Resolução nº 4292/2013 do BACEN)

Os créditos imobiliários que lastreiam a emissão de CRI deverão obedecer o limite máximo de $20 \%$ (vinte por cento), por devedor ou coobrigado. (Art. $5^{\circ}$ da Instrução CVM nº 414/2004)

Nesse cenário, foi somente em 29 de agosto de 2017, em data muito próxima à conclusão deste trabalho, que o Conselho Monetário Nacional editou o único normativo que até hoje veio a tratar, de forma expressa e

\footnotetext{
12 "Dispõe sobre o direcionamento dos recursos captados em depósitos de poupança pelas entidades integrantes do Sistema Brasileiro de Poupança e Empréstimo (SBPE)."

13 "Dispõe sobre a portabilidade de operações de crédito realizadas com pessoas naturais [...] e dá outras providências."

14 "Dispõe sobre o registro de companhia aberta para companhias securitizadoras de créditos imobiliários e de oferta pública de distribuição de Certificados de Recebiveis Imobiliários - CRI."
} 
direta, do conceito de crédito imobiliário. Trata-se da Resolução $\mathrm{CMN} \mathrm{n}^{\circ}$ 4598/2017, editada para disciplinar “a emissão de Letras Imobiliárias Garantidas por parte das instituições financeiras que especifica”.

Em seu artigo 20, a resolução apresenta um rol do que seriam considerados os créditos imobiliários para os fins do referido diploma, isto é, para a disciplina específica das Letras Imobiliárias Garantidas (ou LIGs, em sua abreviação usual ${ }^{15}$ ):

Art. 20. Para fins desta Resolução, consideram-se créditos imobiliários os créditos constituídos por meio das seguintes operações:

I - financiamento para a aquisição de imóvel residencial ou não residencial;

II - financiamento para a construção de imóvel residencial ou não residencial;

III - financiamento a pessoa jurídica para a produção de imóveis residenciais ou não residenciais; e

IV - empréstimo a pessoa natural com garantia hipotecária ou com cláusula de alienação fiduciária de bens imóveis residenciais.

A partir da leitura desse dispositivo, duas observações relevantes podem ser feitas.

Em primeiro lugar, ressalte-se que o rol de hipóteses trazidas nos incisos do artigo 20 possui um claro caráter taxativo - e não exemplificativo -, não sendo possível, portanto, conferir uma interpretação extensiva ao dispositivo ou considerar outras modalidades como operações capazes de constituir o crédito imobiliário, no âmbito das LIGs.

Em segundo lugar, é forçoso reconhecer o alto grau de especificidade das hipóteses trazidas pelo dispositivo. Como se pode observar pela leitura dos incisos, as descrições das operações são completas e bastante

\footnotetext{
${ }^{15}$ De acordo com a Secretaria de Acompanhamento Eletrônico do Ministério da Fazenda (SEAE), a LIG pode ser definida como um "titulo de crédito nominativo, transferivel e de livre negociação, vinculado à Carteira de Garantias submetida ao regime de separação patrimonial.". Trata-se de instrumento equivalente às covered bonds que existem na Europa, possuindo as vantagens de não incidirem no imposto de renda e de serem garantidas por um patrimônio separado pertencente à instituição financeira que emitir o título, o que confere maior segurança aos investidores. (SECRETARIA DE ACOMPANHAMENTO ELETRÔNICO DO MINISTÉRIO DA FAZENDA: Letra imobiliária Garantida - LIG. Disponível em: <https://www.abecip.org.br/download?file=5seminario-abecip-pablo-fonseca-ministerio-da-fazenda1.pdf $>$. Acesso em 22.10.2017).
} 
adjetivadas, tornando mais difícil a ocorrência de eventuais obscuridades e dificuldades de interpretação.

Se, por um lado, um rol específico é capaz de trazer mais segurança jurídica aos operadores do mercado - como se defende neste trabalho -, por outro há de se ter bastante cuidado com a restrição excessiva que pode resultar desse proceder. Como se depreende da leitura do artigo, o rol de hipóteses contempla apenas as operações cujo caráter imobiliário é verificado em sua destinação, posicionamento que, conforme se verá no capítulo 2.3, encontra-se em dissonância com o entendimento atual do Colegiado da CVM, que reconhece tanto os créditos imobiliários caracterizados na origem quanto os caracterizados na destinação.

De fato, não parece o mais apropriado reconhecer um crédito imobiliário pela sua destinação e não reconhecê-lo pela sua origem. Admitir tal possibilidade seria, por exemplo, excluir das possíveis operações os créditos decorrentes de um contrato de arrendamento, muito embora esse tipo de contrato represente, em sua essência, uma legítima exploração de um bem imóvel.

De todo modo, é necessário repisar que a Resolução CMN n 4598/2017 se refere única e exclusivamente à disciplina das LIGs, não servindo, assim, como uma definição abstrata e erga omnes ao conceito de crédito imobiliário. Por tal motivo, é seguro afirmar que, embora possa servir como uma fonte subsidiária e doutrinária para a tarefa de conceituação, a referida resolução não sana a grave omissão legislativa e normativa existente sobre a matéria. Continuamos, pois, sem uma definição legal de crédito imobiliário.

Para que não restem dúvidas acerca de tal afirmação, que, à primeira vista, pode parecer um pouco ousada, faz-se oportuno recorrer às palavras precisas de Chalhub, a seguir transcritas:

Não obstante, a Lei 9.514/1997 não explicita o que seja crédito imobiliário; antes, a ele se refere genericamente. [...] A Lei 10.931/2004, por sua vez, igualmente 
deixa de qualificar a natureza imobiliária do crédito nela espelhado, limitando-se a dispor que a CCI é instituída "para representar créditos imobiliários." (art.18).

[...]

A falta de caracterização tem provocado controvérsia, e trata-se de aspecto relevante, pois os créditos constituem o lastro dos títulos emitidos na securitização e o lastro é que garante o resgate dos títulos. ${ }^{16}$

No mesmo sentido pode-se aludir à opinião de Ivo Waisberg e Herbert Morgestern Kluger, em notável artigo voltado especificamente à análise do conceito de crédito imobiliário no ordenamento jurídico brasileiro:

Contudo, apesar de se referir inúmeras vezes ao crédito imobiliário, a Lei 9.514/1997 não o define ou conceitua, tampouco traz um rol exemplificativo, sendo que as demais normas legais (em particular a Lei 10.931/2004) e infralegais (especialmente a Instrução CVM 414/2004) posteriores incorrem na mesma omissão.

Assim, tem-se que justamente o cerne da securitização imobiliária - o crédito imobiliário - carece de maiores esclarecimentos quantos (sic) aos seus contornos e limites por parte do legislador pátrio, o qual delegou tal tarefa à doutrina e demais operadores de direito, tendo papel de destaque nesta empreitada as decisões do Colegiado da CVM, órgão encarregado de salvaguardar o mercado de capitais. ${ }^{17}$

Sendo desnecessária qualquer delonga em relação à realidade normativa acima descrita, posto que flagrante e evidente, passa-se, então, ao exame do material doutrinário em que se procurou discutir o conceito de crédito imobiliário.

\subsection{Doutrina}

A atividade doutrinária é muito bem vinda em todos os momentos do estudo do jurídico, mas a sua necessidade e a sua importância são mais

\footnotetext{
${ }^{16}$ CHALHUB, Melhim Namem. Negócio Fiduciário. $4^{\mathrm{a}}$ edição. Rio de Janeiro: Editora Renovar, 2009. p. 375.

${ }^{17}$ WAISBERG, Ivo; KUGLER, Herbert Morgenstern. O conceito de crédito imobiliário para fins de securitização imobiliária: Análise e crítica ao posicionamento atual da CVM. Revista de Direito Bancário e do Mercado de Capitais. São Paulo, v. 62, Ano 16, p. 129, out./dez., 2013.
} 
facilmente verificadas quando a legislação, fonte maior do Direito, acaba contendo lacunas, contradições, antinomias, enfim, tudo aquilo que possa ser, de alguma forma, um obstáculo à tarefa dos operadores de aplicar a lei. Quando se está diante de uma omissão legislativa, como é o caso exposto no subcapítulo anterior, nada mais natural do que esperar a existência de uma doutrina forte, atuante e empenhada em superar tais dificuldades e alcançar o melhor entendimento possível no estudo das normas que carecem de uma maior interpretação. Muito surpreendentemente, tal expectativa representa exatamente o oposto do que acontece na presente situação.

Como já se teve a oportunidade de antecipar nos capítulos anteriores, a doutrina brasileira pouco se propôs a analisar e discutir o conceito de crédito imobiliário para o nosso ordenamento jurídico, a despeito de toda a sua relevância prática exaustivamente demonstrada até então. Diante desse cenário de escassez, resta a nós analisar com muito cuidado e atenção os ensinamentos passados pelos autores, sempre analisando-os, quando possível, sob um olhar crítico que também possa contribuir para o enriquecimento do tema.

\subsubsection{Melhim Namem Chalhub}

Para fins de organização do raciocínio, faz-se pertinente inaugurar o presente subcapítulo falando mais uma vez sobre a obra singular de Melhim Namem Chalhub, notório jurista que ganhou destaque por ter sido o primeiro doutrinador a tratar direta e especificamente do conceito de crédito imobiliário. Embora sua visão não seja compatível com o entendimento atual do Colegiado da CVM, conforme se verá mais à frente, não há dúvidas de que a análise de seus estudos é absolutamente indispensável para a formação de um entendimento crítico e completo a respeito da controvérsia. 
Pois bem. Ao longo de suas obras, mais especificamente em $O$ Negócio Fiduciário e Alienação Fiduciária, Incorporação Imobiliária e Mercado de Capitais, ambas já citadas nos capítulos anteriores, Chalhub sustenta que o crédito imobiliário é aquele cuja satisfação está vinculada a um determinado bem imóvel, de modo que o seu conteúdo econômico esteja adstrito ao cumprimento da prestação pelo devedor. Nesse sentido, o crédito será imobiliário sempre que, em havendo inadimplemento ou mora por parte do devedor, o credor possa se apropriar do conteúdo econômico de um bem imóvel que esteja vinculado à prestação eventualmente inadimplida.

O que Melhim quer dizer, em outras palavras, é que a natureza imobiliária do crédito se verifica pela existência de um bem imóvel como garantia das obrigações pactuadas. Nada além disso. De acordo com o raciocínio do autor, se um indivíduo retira $\mathrm{R} \$ 1.000 .000,00$ (um milhão de rais) de sua conta bancária e o empresta a outro indivíduo, exigindo que este, em garantia da devolução da quantia, constitua uma alienação fiduciária de um imóvel em seu favor, esse crédito estabelecido entre ambos possuirá natureza imobiliária, independentemente da origem ou da destinação do valor emprestado de um para o outro. Nessa hipótese, a existência de um bem garantindo a devolução do dinheiro seria o bastante para caracterizar o crédito desse mútuo como imobiliário.

Nas próprias palavras do ilustre doutrinador:

Esse elemento é particularmente relevante no mercado de securitização de créditos imobiliários, visando À segurança jurídica e econômica dos investidores, aspecto que, a nosso ver, conduz à conceituação do crédito imobiliário necessariamente em função do vínculo real que prende certo imóvel à satisfação de determinado crédito, de modo a assegurar-se ao credor o direito de se apropriar do conteúdo econômico do imóvel em caso de mora ou inadimplemento do devedor, obviamente até o limite do valor do seu crédito

[...]

Ora, o que distingue a securitização de créditos em geral, não imobiliários, da securitização de créditos imobiliários é a inexistência ou a existência de bens garantindo o crédito securitizado.

[...]

De outra parte, parece razoável que, visando a ampliação do mercado, com 
segurança jurídica, seja admitida a securitização de créditos oriundos de empréstimos sem finalidade específica, mas garantidos por direito real imobiliário. ${ }^{18}$

\subsubsection{Ricardo Pereira Lira}

O conceito atribuído por Chalhub foi pioneiro e ganhou posição de grande destaque no âmbito da doutrina, servindo até mesmo de inspiração para as ideias que foram sendo produzidas por importantes doutrinadores após a edição das Leis 9.514/1997 e 10.931/2003. Um desses doutrinadores é o renomado professor Ricardo Pereira Lira, que, em parecer jurídico exarado para um advogado no ano de 2003, teve a oportunidade de endossar o entendimento enunciado por Melhim, inclusive citando-o em seus argumentos ao longo da análise.

No âmbito desse parecer, o advogado consulente expôs uma situação complexa envolvendo a emissão de CRIs e $\mathrm{CCI}^{19}$, questionando ao professor, dentre outras coisas, qual seria o conceito de crédito imobiliário de acordo com o direito positivo brasileiro. Para justificar a sua dúvida, o consulente compartilha, de forma muito lúcida, a seguinte análise:

...alguns interpretam restritivamente os dispositivos legais supra citados, na medida em que entendem que a atividade a ser desenvolvida no imóvel objeto do negócio jurídico tenha que ser imobiliária. Em outras palavras, para que os créditos ditos imobiliários possam lastrear uma emissão de CRIs, seria necessário que tais recebíveis decorressem da exploração do imóvel ou do financiamento do imóvel, e não de uma atividade econômica exercida pela tomadora mediata dos recursos, mesmo que tal atividade seja realizada em um imóvel de propriedade desta..20

\footnotetext{
${ }^{18}$ CHALHUB, Melhim Namem. Op. cit., p. 376-377.

${ }^{19}$ Tal situação é o objeto central do Processo Administrativo CVM no RJ2003/5639, relatado pela então Diretora do Colegiado da CVM Norma Jonssen Parente. Esse processo será analisado individualmente quando da análise dos precedentes da CVM a respeito do conceito de crédito imobiliário (Capítulo 3.3. do presente trabalho).

${ }^{20}$ PEREIRA LIRA, Ricardo. Crédito Imobiliário e sua conceptuação. A revogação da categoria dos bens imóveis por acessão intelectual pelo Código Civil Brasileiro de 2002: consequências. As pertenças e seu regime jurídico. A securitização. Os recebíveis: Créditos Recebíveis Imobiliários (CRIs) e as Cédulas de Crédito Imobiliário (CCIs). O Continuum Imobiliário como lastro da emissão desses títulos mobiliários. Revista Forense. Belo Horizonte, v. 100, n 373, p. 205, maio/jun., 2004.
} 
A ponderação do advogado faz todo o sentido para a situação, uma vez que, segundo o relatado, o imóvel cuja compra e venda ensejaria a emissão de CRI seria utilizado para atividades de geração de energia, e não para fins de exploração imobiliária. Dessa forma, a eventual confirmação desse entendimento - de que a atividade a ser exercida deve ser imobiliária - inviabilizaria a emissão dos CRIs pretendida pelo consulente e por seus clientes.

Em resposta ao questionamento do advogado, o Professor Ricardo Pereira Lira afirma que a natureza imobiliária do crédito pode ser constatada de duas formas possíveis: pelas suas garantias ou pelo vínculo com a prestação. No que diz respeito às garantias, o professor expõe entendimento alinhado ao de Chalhub, argumentando que “...crédito imobiliário é aquele que consubstancia uma prestação ligada a um imóvel, e ainda é aquele cuja garantia se funda na propriedade imóvel: hipoteca, anticrese, propriedade fiduciária de um imóvel,21. E ainda traz um exemplo:

Um banco de fomento, por exemplo, financia um determinado projeto (project finance), e se garante, não apenas com os recebíveis, mas fortalece sua posição com uma garantia hipotecária. $\mathrm{O}$ crédito, nesse caso, é um crédito imobiliário. ${ }^{22}$

Já em relação ao vínculo com a prestação - aspecto este que não é trazido por Chalhub -, o professor defende que, além da possibilidade de caracterização pela existência de garantia real, um crédito também pode ser considerado imobiliário pela vinculação da obrigação pactuada com um bem imóvel, ainda que essa obrigação, no caso concreto, não possua qualquer garantia.

O que o Prof. quer dizer, ao estabelecer esse critério, é que um crédito será imobiliário sempre que o objeto da relação obrigacional estiver

\footnotetext{
${ }^{21}$ Ibid. p. 207.

${ }^{22}$ Ibid. p. 207.
} 
relacionado a um bem imóvel, seja uma obrigação de dar, seja uma obrigação de fazer. Nas próprias palavras do autor, tanto um contrato de compra e venda de um imóvel (obrigação de dar) quanto uma obrigação de fazer que desague na aquisição de um imóvel constituirão um crédito imobiliário, uma vez que, em ambos os casos, os objetos das obrigações possuem vínculo com uma propriedade imobiliária.

Explica o professor:

A prestação é, por conseguinte, o objeto da obrigação. Vista passivamente é o débito. Vista ativamente é o crédito.

Esse débito ou esse crédito podem estar diretamente ligados a um bem móvel ou diretamente ligados a um bem imóvel. No primeiro caso o débito e o crédito são mobiliários. No segundo, o débito e o crédito são imobiliários.

Essa é a noção de crédito imobiliário quando concebida a situação em face da categoria do bem (imóvel) a que está diretamente ligada a prestação objeto da relação obrigacional. ${ }^{23}$

Dessa forma, Ricardo Pereira Lira complementa o raciocínio de Chalhub e admite a caracterização do crédito tanto pela garantia quanto pelo objeto da prestação. Ressalte-se que essas duas possibilidades se dão de forma alternativa, de modo que a existência de apenas um desses critérios já seria o bastante para conferir o caráter imobiliário à relação obrigacional.

Após dar o seu parecer acerca dos quesitos formulados, o Prof. Ricardo Lira ainda elucida, ao final, a dúvida do advogado consulente no que diz respeito à obrigatoriedade - ou não - de ser imobiliária a atividade a ser exercida no imóvel que foi objeto da obrigação. O posicionamento é muito claro:

Outro ponto a ser sublinhado é o de que, seja na Lei $n^{\circ}$ 9.514/97, seja na Medida Provisória ${ }^{\mathrm{o}} 2.223 / 01^{24}$, não se encontra qualquer exigência no sentido de que a

\footnotetext{
${ }^{23}$ Ibid. p. 207.

${ }^{24}$ A Medida Provisória no 2.223/01 regulamentava a Letra de Crédito Imobiliário e a Cédula de
} 
atividade a ser desenvolvida no imóvel objeto do negócio jurídico gerador das CCIs ou dos CRIs tenha que ser imobiliária.

Incensurável a parte expositiva da Consulta ora respondida, quando salienta que a Lei $n^{\circ} 9.514 / 97$, especialmente no art. $6^{\circ}$, bem como a respectiva exposição de motivos ministerial, não referem, como pressuposto da securitização, que no imóvel se exerça atividade imobiliária. Do mesmo modo a Medida Provisória $\mathrm{n}^{\circ}$ $2.223 / 01{ }^{25}$

\subsubsection{Arthur Rios Jr.}

Além dos dois posicionamentos expostos até então, uma terceira e importantíssima linha de pensamento diz respeito à conceituação do crédito imobiliário tão somente pela sua origem, sem levar em consideração eventual garantia que venha a suportar a obrigação. Um dos autores adeptos a essa tese é o advogado Arthur Rios Jr., que, em seu artigo Securitização de Créditos Imobiliários, defende que a existência de uma garantia real da obrigação não é parâmetro válido para classificar um crédito como imobiliário, sendo necessário olhar única e exclusivamente para a origem da relação obrigacional.

De acordo com esse juízo, o caráter acessório da garantia impediria que esta definisse, por si só, a natureza de um crédito, valendo a máxima de que o acessório segue o principal. Logo, o correto seria olhar para o principal da relação obrigacional, e não para a sua garantia. Diz Arthur:

Pensamos que a origem dos créditos é o elemento central que deve permear a caracterização do crédito como imobiliário ou não. A natureza imobiliária do credito não pode ser conceituada exclusivamente em decorrência de sua garantia, que é acessória.

$[\ldots]$

Sustentar que um crédito pode ser considerado imobiliário para fins de securitização, pela simples vinculação deste a uma garantia real, possibilitaria a transposição de toda a sistemática criada pela Lei $\mathrm{n}^{\circ}$ 9.514/97, para todos os demais setores da economia. Entendemos, portanto, que a melhor forma de conceituar crédito imobiliário para fins de securitização é a partir de sua ligação,

Crédito Imobiliária até 2004, ano em que foi revogada pela Lei 10.931/2004.

${ }^{25}$ PEREIRA LIRA, Ricardo. Op. cit., p. 215. 
na origem, a uma atividade imobiliária. ${ }^{26}$

Em uma tentativa de situar melhor o leitor quanto aos seus critérios, Arthur Rios dá alguns exemplos do que poderia ser considerada uma relação imobiliária a partir de sua origem, mencionando "mútuos para a aquisição, a construção, a ampliação ou a reforma de um imóvel, bem como os originados de sua exploração, como, por exemplo, de locações, cessões de direito real de superficie e built to suit ${ }^{, 2}{ }^{27}$

Sem pretender entrar no mérito da conceituação, peça-se, aqui, a devida vênia para divergir do autor especificamente quanto à terminologia utilizada na sua respeitável tese. Quando se exemplifica um crédito imobiliário por "mútuos para a aquisição, a construção, a ampliação ou a reforma de um imóvel", não se está, em momento algum, caracterizando esse crédito a partir da sua origem, mas sim a partir de sua destinação.

Isto porque a aquisição, a construção, a ampliação ou a reforma de um imóvel é realizada em momento posterior à constituição do crédito, não guardando relação direta e específica com a sua natureza. Em um primeiro momento, a relação obrigacional é constituída, e, depois, o devedor destina o capital obtido para determinada finalidade, de modo que o "principal" do crédito - consoante a terminologia utilizada no artigo - não possui relação direta com o imóvel em comento. Nessa hipótese, a afetação do imóvel representa tão somente a etapa de destinação.

Ultrapassado esse pequeno adendo, outra pertinentíssima ponderação do autor diz respeito à impossibilidade, a seu ver, de se caracterizar o crédito imobiliário única e exclusivamente pela existência de garantia real, diferentemente do que defendem Chalhub e Ricardo Pereira Lira. Segundo ele, a possibilidade de se emitir uma CCI sem garantia permitiria que um crédito imobiliário também o fosse, sobretudo se considerado que uma CCI nada mais é do que a representação de um determinado crédito. Em suas

\footnotetext{
${ }^{26}$ RIOS JUNIOR, Arthur. Op. cit., p. 79.

${ }^{27}$ Ibid. p. 79.
} 
próprias palavras:

Assim como a Lei ${ }^{\circ}$ 9.514/97, a Lei $n^{\circ} 10.931 / 04$ não conceitua o que seria crédito imobiliário. Todavia, autoriza a emissão de CCI com ou sem garantia. Logo, por mais essa razão, subentende-se que não seria pressuposto do conceito de crédito imobiliário uma relação de direito real deste com imóveis. ${ }^{28}$

\subsubsection{Ivo Waisberg e Herbert Morgenstern Kugler}

Como já se teve a oportunidade de mencionar ao longo deste trabalho, os mestres Ivo Waisberg e Herbert Morgenstern Kugler são autores de um excelente artigo voltado à discussão do conceito de crédito imobiliário e a uma crítica ao entendimento da CVM à época de sua edição (dezembro de 2013). Considerando que essa crítica será oportunamente analisada no capítulo 4, o presente subitem obedecerá aos objetivos deste capítulo e abordará apenas as lições que disserem respeito ao conceito de crédito imobiliário propriamente dito.

Em uma visão bastante abrangente, os autores defendem que o crédito imobiliário deve ser caracterizado a partir da "causa" do negócio jurídico que dê origem à dívida. De acordo com a definição trazida no artigo, o termo "causa" deve ser compreendido como a vinculação de um negócio jurídico a um determinado fim, expressando, assim, a função econômico-social inerente a cada negócio jurídico.

De acordo com esse raciocínio, seriam créditos imobiliários aqueles derivados de negócios jurídicos que possuíssem causas relativas a bens de natureza imóvel, mais especificamente "bens imóveis, direitos reais sobre bens imóveis ou a uma utilidade econômica sobre tais bens e direitos, seja para fins de transferência, locação, aquisição, comodato, financiamento etc. ${ }^{, 29}$. Aduzem os mencionados autores:

\footnotetext{
${ }^{28}$ Ibid. p. 87.

${ }^{29}$ WAISBERG, Ivo; KUGLER, Herbert Morgenstern. Op. cit., p. 138.
} 
É justamente essa causa comum, presente em todos os negócios jurídicos imobiliário, que classifica o crédito que emerge do negócio com imobiliário ou não. Assim, será crédito imobiliário aquele oriundo de negócio jurídico imobiliário, cuja causa - isto é, função econômico-social -, é relativa a bens imóveis, direitos reais sobre bens imóveis ou a uma utilidade econômica sobre tais bens e direitos.

Com base nessa fundamentação, conclui-se que há crédito imobiliário nas obrigações decorrentes de financiamento para aquisição de bens imóveis, compromissos de venda e compra, locação, dentre outros, exatamente em razão da causa dos referidos negócios. ${ }^{30}$

Já quanto à possibilidade de caracterizar os créditos imobiliários pela mera existência de uma garantia real, os autores seguem o mesmo raciocínio exposto por Arthur Rios Jr. e defendem a impossibilidade de tal caracterização, uma vez que, nesses casos, a garantia não integraria a essência da dívida em questão:

\begin{abstract}
No entanto, não se enquadra como crédito imobiliário aquele decorrente do mútuo garantido por hipoteca ou outro direito real, uma vez que não basta qualquer vinculação com determinado bem imóvel no que se refere ao pagamento do crédito. Deveras, um mútuo garantido por um bem imóvel não tem, na sua essência, qualquer conotação ou causa imobiliária, sendo que seria necessário configurar o inadimplemento do contrato para, justamente, relacionar-se o bem imóvel ao negócio. Assim, a vinculação com o imóvel, direito real ou utilidade econômica dele derivada, deve remontar ao início da relação obrigacional que originou o crédito, encontrando-se na causa daquele negócio jurídico. ${ }^{31}$
\end{abstract}

\title{
2.2.5. Gladston Mamede
}

Um quinto e último posicionamento que não poderia deixar de ser mencionado é aquele adotado pelo ilustríssimo Gladston Mamede, que, em seu artigo Letra de Crédito Imobiliário e Cédula de Crédito Imobiliário Segundo a Lei 10.931, de 02 de agosto de 2004, sustenta que o conceito de crédito imobiliário deve ser interpretado de acordo com o contexto da mencionada lei, sendo, nesse sentido, um termo correspondente a "contratos

\footnotetext{
${ }^{30}$ Ibid. p. 138.

${ }^{31}$ Ibid. p. 138-139.
} 
de financiamentos de bem imóveis". Argumenta Mamede, ao discorrer sobre os instrumentos cambiários que fazem parte do mercado imobiliário:

\begin{abstract}
A expressão créditos imobiliários, nesse contexto, interpreta-se como contratos de financiamento de bem imóveis; em tais contratos aferem-se os aludidos créditos imobiliários, do qual a emissora é credora, e que são utilizados na letra como garantia pignoratícia obrigatória.

$[\ldots]$

Pelo que se apura do geral da norma, a cédula de crédito imobiliário e a letra de crédito e a letra de crédito imobiliário foram pensadas como instrumentos distintos, mas de única finalidade: permitir a captação de recursos para o financiamento da construção civil, a partir da antecipação de receitas futuras. Para tanto, pensaram-se dois títulos como instrumentos que representariam, cada qual por uma estrutura própria, créditos oriundos de contratos de financiamento imobiliário;",32
\end{abstract}

Em que pese o já conhecido brilhantismo do autor, o conceito apresentado acima esbarra na dificuldade de se precisar o que poderia ser considerado um contrato de financiamento de bens imóveis, de modo a proporcionar, como se espera, a segurança necessária àqueles que buscam operar com crédito imobiliário no mercado. Imaginem-se duas situações: (i) na primeira, uma incorporadora faz a planta de um prédio e - como normalmente ocorre - vende todas as suas unidades antes mesmo de começar a construção. Em seguida, ela separa os contratos de compra e venda de algumas das unidades, representando créditos a longo prazo, e os cede a uma companhia securitizadora, a qual os utiliza como lastro para a emissão de um CRI a ser despejado no mercado. No ato da compra do CRI, um investidor adianta os recursos à incorporadora, que, a partir desse financiamento, finalmente começará a construção do seu empreendimento; (ii) na segunda hipótese, uma família vai até um banco e pede um empréstimo em moeda corrente nacional a ser utilizado na aquisição de um imóvel. O banco concede o empréstimo.

Tecnicamente, ambas as hipóteses expressam situações de financiamento imobiliário, mas é forçoso reconhecer que elas possuem mais diferenças do que semelhanças. A principal delas é que, na primeira, o

\footnotetext{
${ }^{32}$ MAMEDE, Gladston. Op cit., p. 53-57.
} 
crédito é imobiliário pela origem, na medida em que é constituído por recebíveis de contratos de compra e venda das unidades do prédio. $\mathrm{Na}$ segunda, diversamente, o crédito é constituído por moeda corrente nacional e se caracteriza como imobiliário somente a partir de sua destinação, que é, no exemplo dado, a aquisição do apartamento pela família.

Pergunta-se: mesmo com essa diferença fundamental, ambos podem ser igualmente considerados créditos imobiliários? Isto é, a tese de Mamede se aplica a todos os contratos de financiamento imobiliário, sejam eles caracterizados pela origem, sejam eles caracterizados pela destinação? A resposta para tal questionamento não fica explícita a partir do artigo examinado, embora devamos considerar, por uma questão de razoabilidade e correção, que a definição genérica expressa a intenção do autor de abarcar todos os contratos que possam representar uma situação de financiamento de bem imóvel, seja qual for o meio de sua caracterização.

\subsubsection{Conclusão}

Assim sendo, o estudo da tese de Mamede representa o desfecho de nossas análises em relação à doutrina brasileira. De tudo o que se viu, é possível concluir, para fins didáticos, que todos os posicionamentos examinados podem ser classificados em três grandes métodos de conceituação do crédito imobiliário: o da origem, o da vinculação e o da destinação. É o que muito corretamente asseveraram Ivo Waisberg e Herbert Morgenstern Kugler, em artigo de sua autoria:

\footnotetext{
Nos debates travados, é possível identificar três principais correntes acerca do conceito de crédito imobiliário, a saber: (a) aquela que defende que o crédito será imobiliário quando sua origem decorrer de um imóvel ou da exploração de um imóvel (como o crédito oriundo da venda ou da locação de um bem imóvel); (b) aquela que entende que o elemento caracterizador do crédito imobiliário está na destinação dos recursos (como o mútuo contraído para adquirir, construir ou reformar um imóvel); e (c) aquela que sustenta que será imobiliário o crédito oriundo de uma relação jurídica na qual um imóvel está atrelado ao adimplemento da prestação devido pelo devedor (como um mútuo, sem finalidade
} 
específica, que tenha como garantia do devedor um imóvel ou direito real sobre imóvel)." ${ }^{33}$

A despeito dessa divisão de correntes, estabelecida para fins conceituais e didáticos, é interessante notar que cada um dos autores apresentados é responsável pela elaboração de uma tese única e divergente das teses dos demais. Nenhuma tese é inteiramente alinhada à outra, ainda que ambas pertençam à mesma corrente. Tal constatação é capaz de demonstrar, como já havia sido antecipado, que a doutrina brasileira ainda não conseguiu alcançar um consenso no que diz respeito ao conceito de crédito imobiliário segundo as previsões da lei.

Se por um lado esse panorama pode ser negativo, pela criação de uma insegurança jurídica no mercado, por outro há de se reconhecer que o altíssimo nível de cada um desses doutrinadores influencia positivamente a qualidade do debate proposto, preparando um terreno menos espinhoso para embasar a atuação dos órgãos reguladores diante dos casos concretos.

São esses casos, justamente, o objeto da análise a ser realizada no capítulo a seguir.

${ }^{33}$ WAISBERG, Ivo; KUGLER, Herbert Morgenstern. Op. cit., p. 129-130. 


\section{Precedentes e Atuação Reguladora}

Concluídas as análises da legislação e da doutrina - que constituem, em conjunto, uma visão mais teórica acerca do tema -, o presente capítulo tem o objetivo de examinar os casos concretos em que o conceito de crédito imobiliário foi discutido e aplicado em situações do chamado "mundo real". Desde já, é possível adiantar que essa exposição será limitada aos precedentes estabelecidos pelo Colegiado da CVM, que, em um número considerável de oportunidades, foi o único órgão regulador que até hoje confrontou a controvérsia e se posicionou a respeito da conceituação, aplicando seus entendimentos no âmbito dos diversos processos administrativos que serão aqui analisados. Não foram encontrados registros de que essa discussão tenha chegado, em grau recursal, à alçada do CRSFN.

Para finalizar essa pequena introdução, é necessário esclarecer que os processos a seguir não serão esmiuçados quanto à totalidade de seus fatos e detalhes, mas, por motivos de organização e eficiência, apenas quanto aos pontos que forem relevantes para a análise do tema em comento. Por esse mesmo motivo, o presente trabalho não analisará a totalidade dos processos administrativos que envolveram a discussão do tema, mas somente aqueles que possuírem relevância em termos de precedente.

Com isso, busca-se evitar uma possível confusão informacional e conferir maior produtividade às reflexões que eventualmente venham a ser realizadas no decorrer da leitura.

\subsection{Processo Administrativo CVM no RJ2001/1981 - Diretor Relator Wladimir Castelo Branco Castro. Julgamento em 14.05.2002. ("Caso WT Administradora")}

O Processo Administrativo RJ2001/1981 teve origem em uma consulta realizada pela Administração e Participações Walter Torre Júnior 
Ltda. ("WT Administradora") ao Colegiado da CVM, no ano de 2001, e ficou conhecido por ter sido o primeiro processo administrativo em que a Autarquia analisou e julgou um caso envolvendo a discussão do conceito de crédito imobiliário.

De forma resumida, a WT Administradora era uma sociedade limitada cuja atividade consistia em adquirir terrenos, construir galpões industriais sob medida e alugar os galpões aos seus clientes, que os utilizavam, mediante o pagamento de um aluguel, por um prazo médio de 10 (dez) anos. Tendo em vista a realização dessa atividade, a WT Administradora procurou a CVM e a questionou, dentre outras coisas, se os aluguéis decorrentes da utilização dos galpões poderiam ser objeto de securitização nos termos da Lei 9.514/1997, de modo a lastrear a emissão de um CRI segundo a estrutura operacional pretendida.

Após longos debates travados entre a WT Administradora e a Procuradoria Jurídica da CVM ("PJU”), que divergiam acerca de diversos pontos da consulta, o Colegiado pôs fỉm à controvérsia e se manifestou unanimemente no sentido de que os aluguéis decorrentes de locações comerciais podem, sim, ser securitizados nos termos da Lei 9.154/1997, uma vez que o referido diploma legal não veda tal modalidade de securitização. Nesse sentido, afirmou o Diretor Relator:

\footnotetext{
Contudo, considerados os demais aspectos acima descritos, entendo que créditos decorrentes de locações comerciais podem ser securitizados nos termos da Lei 9.514/97, já que esta não veda expressamente tal modalidade, mesmo que tais créditos não se originem de operações de financiamento no âmbito do SFI ou fora dele.
}

Embora seja pertinente ao tema, nota-se que a decisão desse processo apenas confirma uma hipótese específica do que poderia ser considerado crédito imobiliário, sem pretender discutir a construção do conceito em relação aos seus critérios universais. É o que será observado nos próximos casos. 


\subsection{Processo Administrativo CVM no RJ2002/3032 - Diretor Relator Luiz Antonio de Sampaio Campos. Julgado em 13.05.2003. ("Caso CIBRASEC")}

O Processo Administrativo RJ2002/3032 originou-se de um pedido de concessão de registro para a emissão de CRIs, no ano de 2002. De acordo com a estrutura operacional exposta, os recebíveis decorrentes da comercialização de energia elétrica pela Companhia Energética Paulista EP ("CESP") seriam cedidos à Companhia Brasileira de Securitização ("CIBRASEC"), que, por sua vez, utilizaria esses créditos como lastro para a emissão de um CRI. Ao final, os recursos obtidos com a venda do CRI seriam utilizados para a ampliação e para a reforma de uma usina hidroelétrica de propriedade da CESP.

Com base nessa estrutura, a CIBRASEC realizou o pedido de registro do CRI à Superintendência de Registro de Valores Mobiliários da CVM ("SRE") e esta o denegou, sustentando, dentre outras razões, que " $a$ espécie de operação originária informada não seria condizente com o disposto no artigo $6^{\circ}$ da Lei $n^{\circ}$ 9.514/97”. Inconformada, a CIBRASEC interpôs recurso apoiado em pareceres da Associação Brasileira das Entidades de Crédito Imobiliário e Poupança e de escritório de advocacia especializado, todos no sentido de que o crédito se caracteriza como imobiliário pela existência de uma destinação específica dos recursos para um determinado imóvel.

Diante da manutenção da decisão originária pela SRE, dessa vez com o apoio de um parecer da PJU, a CIBRASEC interpôs um recurso ao Colegiado da Autarquia, reiterando seu entendimento de que os recebíveis destinados à ampliação e à reforma da usina seriam créditos imobiliários aptos a lastrear a emissão pleiteada. Não obstante, o Colegiado acompanhou o posicionamento da SRE e da PJU e negou provimento ao recurso interposto. 
Em seu voto, acompanhado pelo restante dos membros do Colegiado, o Diretor Relator Luiz Antonio Sampaio Campos foi categórico ao afirmar que o crédito imobiliário se caracteriza pela sua origem, e não pela sua destinação. Nesse sentido, os créditos decorrentes de contratos de comercialização de energia não estariam originariamente atrelados a um imóvel e, portanto, não estariam aptos a lastrear a emissão do CRI. Nas palavras do Diretor Relator:

15. A par do entendimento manifestado pela Recorrente, parece-me que a PJU foi precisa em sua manifestação de fls. 285/291, ao esclarecer que a intenção da lei foi estabelecer como crédito imobiliário aquele que surge, ou garante-se, dos frutos e rendimentos de um imóvel ou de negócio imobiliário.

16. Nesse passo, para que créditos ditos imobiliários possam lastrear uma emissão de certificados de recebíveis imobiliários, seria necessário que tais recebíveis decorressem da exploração do imóvel ou do financiamento do imóvel, e não de uma atividade econômica exercida pela tomadora mediata dos recursos, mesmo que tal atividade seja realizada em um imóvel de propriedade desta.

$[\ldots]$

17. Dito de outro modo, parece-me que o crédito é imobiliário pela origem e não pela destinação.

Nota-se, ademais, que o conceito de origem exposto pelo Diretor Relator parece admitir a caracterização do crédito pela mera existência de garantia real à obrigação pactuada, conforme se depreende do trecho “...estabelecer como crédito imobiliário aquele que surge, ou garante-se, dos frutos e rendimentos de um imóvel ou de negócio imobiliário. ”(grifouse). A boa gramática e a boa interpretação indicam que os requisitos expostos pelo Diretor Relator são alternativos, isto é: ou o crédito imobiliário surge de um imóvel, ou por ele se garante. A utilização da palavra "ou” parece não deixar dúvidas quanto a isso.

Observe-se, por fim, que tal entendimento caminha em sentido diverso do parecer da PJU, que dá a entender que a origem e a garantia seriam critérios cumulativos - e não alternativos - para a caracterização do crédito imobiliário, devendo ambos estar presentes para que seja possível o 
enquadramento. Veja-se a seguinte fundamentação do parecer da PJU, segundo resumo constante do relatório da ata:

ii. o crédito imobiliário terá que, obrigatoriamente, originar-se e garantir-se do imóvel ou em bens pertencentes ao SFI, guardada e observada a indispensável relação de pertença para com o bem imóvel, com o bem de raiz.

iii. o imóvel deverá ser o bem principal e gerar o acessório, gerador de recebíveis, inclusive garantindo-o já que serão lastro à sucedente emissão dos CRIs. (grifouse)

Em que pese o respeitável posicionamento da PJU, a presente análise de precedentes deve levar reconhecer a predominância da tese esposada pelo Colegiado da Autarquia, segundo a qual o crédito imobiliário pode ser caracterizado, alternativamente, pelo seu surgimento a partir de um imóvel ou pela utilização de um imóvel como garantia da obrigação avençada.

\subsection{Processo Administrativo CVM no RJ2003/5639 - Diretora Relatora Norma Jonssen Parente. Julgamento em 18.11.2003. ("Caso Maxpower")}

O Processo 2003/5639 é mais um pedido de registro de distribuição pública de CRIs endereçado à SRE. Como mencionado na nota de rodapé $\mathrm{n}^{\circ}$ 19, esse processo possui a particularidade de já ter sido debatido - ainda que superficialmente - no decorrer do presente trabalho, uma vez que os mesmos fatos geradores do pedido de registro também foram objeto do parecer do Prof. Ricardo Pereira Lira examinado no Capítulo 2, quando foi analisada a doutrina relativa ao conceito de crédito imobiliário.

Diferentemente daquela oportunidade, porém, agora se faz necessária uma análise mais detalhada acerca dos fatos que compõem o referido processo. Em janeiro de 2003, a Maxpower do Brasil LTDA. ("Maxpower") firmou uma promessa de compra e venda com a Companhia Energética Paulista (“CESP”), visando, por meio desse contrato, a alienar 
os ativos de uma determinada usina hidroelétrica de sua propriedade. Logo em seguida, a Maxpower emitiu duas CCIs para representar o crédito obtido com a alienação dos ativos da usina hidroelétrica e as cedeu à Brazilian Securities Companhia de Securitização ("Brazilian Securities”), a qual, tomando as CCIs como lastro, fez o pedido de registro de CRIs que deu origem ao processo administrativo em análise. Destaque-se, ainda, que promessa de compra e venda avençada entre as partes era garantida por bens imóveis.

Quando o processo chegou à alçada do Colegiado, em grau recursal, a Diretora Relatora concluiu que a operação proposta pela requerente não se caracterizava um empreendimento propriamente imobiliário, uma vez que, a seu ver, a Lei 9.514/1997 seria um normativo destinado especificamente ao setor habitacional, à criação de emprego e ao crescimento da economia, objetivos que não se verificariam no lastro dos CRIs cujo registro era pleiteado.

De acordo com a tese esposada, portanto, o contrato de promessa de compra e venda de ativos pertencentes a uma usina hidroelétrica não seria apto a lastrear um CRI com base na Lei 9.514/1997, tendo em vista se tratar de uma atividade estritamente econômico-produtiva e não de uma atividade voltada à moradia e à criação de emprego. Reza o voto apresentado:

Conclui-se com convicção que esta Lei visa criar as condições para mobilizar um volume crescente de recursos para o setor habitacional, com o que se estará atingindo três objetivos fundamentais: geração de renda e empregos, ampliação do acesso da população à moradia e promoção do crescimento sustentado da economia.

Todavia, não são estes os objetivos que a compra e venda em análise pretende alcançar. De plano ressalta-se que o objeto desse contrato - a usina e suas pertenças - de forma alguma poderá atender ao fim de gerarem-se empregos através da construção civil, uma vez que o conjunto de bens formado pela usina e suas pertenças materiais já se encontram construídos, falando-se apenas em "repotencialização" dessa universalidade. A ampliação do acesso à moradia também não pode ser alcançada, visto que trata-se da alienação de um empreendimento empresarial de cunho industrial cujo objeto será a produção de energia. 
Assim, infere-se que o pedido de registro definitivo em tela se afasta sobremaneira da finalidade perseguida com a criação do CRI, razão por que não se pode deferi-lo. Não se vislumbra, neste negócio jurídico, um empreendimento propriamente imobiliário, nos moldes a que visa proporcionar a Lei do SFI.

Apesar de esse entendimento não afetar puramente o conceito de crédito imobiliário - mas, de uma forma mais abrangente, a viabilidade das operações de securitização previstas na Lei 9.514/1997 -, vale ressaltar que, em seu voto, a Diretora Relatora mencionou o "Caso CIBRASEC" e endossou o entendimento do Diretor Relator Luiz Antonio de Sampaio Campos no sentido de que o crédito imobiliário se caracteriza pela origem, e não pela destinação.

Por outro lado, note-se que a existência de garantia real na operação proposta pela Brazilian Securities não foi sequer mencionada pela Diretora Relatora, dando a entender, diferentemente do Caso CIBRASEC - no qual a existência de garantia real foi tratada como um critério alternativo -, que esse aspecto não seria aplicável para a caracterização de um crédito como imobiliário. Afinal, se aplicável fosse, o crédito em comento teria que ser qualificado como imobiliário, pois, como visto, as CCIs emitidas pela Maxpower para lastrearem os CRIs contavam com diversas garantias de natureza real. Como a Diretora Relatora rechaçou a natureza imobiliária do crédito, mesmo existindo a garantia, é possível presumir que o entendimento do Colegiado foi no sentido de que esse não seria um requisito válido para a sua caracterização.

Por óbvio, tal conclusão é gerada a partir de uma interpretação que ora se dá à decisão em análise, admitindo-se, se for o caso, eventuais interpretações em sentido diverso. O que se pode assegurar, com toda a certeza, é que a Diretora Relatora se omitiu quanto à caracterização do crédito imobiliário pela existência de garantia real.

Dessa forma, o que se extrai do julgamento do presente caso é (i) a manutenção do entendimento da caracterização do crédito imobiliário pela 
origem e (ii) a omissão do entendimento quanto à caracterização pela existência de garantia real, ambos anteriormente esposados pelo Diretor Relator Luiz Antonio de Sampaio Campos no julgamento do Caso CIBRASEC.

\subsection{Processos Administrativos CVM nos RJ2006/6950 e RJ2007/0547 \\ - Diretor Relator Marcelo Fernandez Trindade. Julgamento conjunto em 10.07.2007. ("Caso Rio Bravo")}

Ainda que as particularidades dos Processos Administrativos 2006/6905 e 2007/0547 nunca tenham ficado claras ao público em geral, desconhecendo-se o teor individual de cada um e o porquê de eles terem sido julgados em conjunto, fato é que ambos os processos representam mais um pedido de registro de distribuição de CRIs que foi indeferido pela SRE e submetido ao Colegiado da CVM em nível recursal.

Dessa vez, a estrutura da operação previa que um determinado shopping centre ("Shopping") reunisse créditos decorrentes dos aluguéis de suas salas comerciais e os cedesse à Rio Bravo Crédito Companhia de Securitização ("Rio Bravo"), a fim de que esta, utilizando tais créditos como lastro, realizasse a emissão de uma série de CRIs a serem oferecidos ao mercado. O detalhe, nesse caso, é que os créditos que a Rio Bravo pretendia securitizar abrangiam tanto os recebíveis já existentes no momento da securitização, representados pelos contratos de locação já firmados, quanto os recebíveis futuros, representados por um fluxo esperado de contratos de locação a serem firmados em momento posterior à securitização dos créditos.

Apesar dos esforços da requerente, a SRE não simpatizou com a inovação trazida pelo Shopping e pela Rio Bravo e indeferiu o pedido de registro dos CRIs, alegando, em consonância com parecer exarado pela PFE, que não é possível securitizar créditos decorrentes de contratos ainda não existentes no momento da securitização, como era o caso das locações 
que seriam realizadas nas salas comerciais de propriedade do Shopping. Em seu parecer, a PFE foi ainda mais longe, afirmando que "não se pode nem classificar os referidos 'créditos' como futuros ou não performados, haja vista que não há indicação de quaisquer instrumentos jurídicos efetivamente celebrados que possam justificar seu recebimento futuro. [...] não existe nem devedor, nem credor, nem obrigação. ”.

Como de costume, o Colegiado indeferiu o recurso da requerente e manteve a decisão proferida pela SRE. Em seu voto, acompanhado pelos demais membros do Colegiado, o Diretor Relator Marcelo Fernandez Trindade repisou uma diferença importante entre os conceitos de "crédito" e de "direito creditório", relembrando que, enquanto o primeiro se refere a um crédito perfeitamente constituído e determinado, o segundo diz respeito a créditos de existência futura, embora derivados de uma relação jurídica já constituída.

Com base nesses conceitos, o Diretor Relator sustentou que a expressão "crédito imobiliário" se refere, necessariamente, a um crédito de existência atual e constituída, de modo a não se admitir a emissão de um CRI com lastro em meros direitos creditórios de existência futura. Além disso, a exigência de que o Termo de Securitização ${ }^{34}$ forneça a identificação do devedor e o valor nominal de cada crédito seria mais um indício de que o CRI, na qualidade de título de crédito, somente pode ser emitido com lastro em créditos que já existam no momento da operação de securitização.

Argumenta o Diretor Relator:

Portanto, concordo em que os ativos passíveis de securitização por meio de CRI são os créditos imobiliários, e não os direitos creditórios de origem imobiliária adotando-se a distinção antes referida. Isto é: é preciso que o crédito esteja constituído, e seu valor seja determinado, para que se possa proceder à emissão de CRI com base nele. E isto se dá porque o CRI é um título de crédito criado por

\footnotetext{
${ }^{34}$ De acordo com o art. $8^{\circ}$ da Lei 9.514/1997, o Termo de Securitização é o instrumento jurídico por meio do qual é formalizada uma operação de securitização, fornecendo, em seu texto, uma série de informações obrigatórias a respeito da operação em questão. Além disso, como já mencionado, o Termo de Securitização é instrumento de lavramento exclusivo das companhias de securitização.
} 
lei, cujas características não podem ser alteradas pela CVM.

[...]

Logo, os aluguéis que ainda virão a ser contratados, seja sobre imóveis desocupados, seja sobre imóveis que ainda virão a ser construídos (a futura expansão do shopping center), não se constituem em créditos imobiliários (e talvez nem mesmo em direitos creditórios). Já os aluguéis decorrentes da renovação futura de contratos de locação hoje existentes, também não constituem créditos imobiliários, mas talvez possam ser considerados como direitos creditórios.

Sendo assim, a decisão do Caso Rio Bravo foi responsável por trazer à tona um novo requisito aplicável à securitização dos créditos imobiliários: a sua contemporaneidade obrigatória. Quanto ao restante dos critérios que vinham sendo aplicados nas decisões anteriores, o Diretor Relator Marcelo Trindade não manifestou expressamente a sua opinião, mas consignou que a intepretação da CVM acerca do conceito vem evoluindo e mencionou os entendimentos expostos pelo Colegiado no Caso WT Administradora e no Caso CIBRASEC. Em relação a esse último, é interessante notar, mais uma vez, a sobrevivência do entendimento do Diretor Luiz Antônio Sampaio Campos no sentido de que o crédito imobiliário deve ser caracterizado pela sua origem, e não pela sua destinação.

Até o momento da presente decisão (Caso Rio Bravo) - e nela inclusive -, é possível afirmar, com certa tranquilidade, que os critérios que vigoravam no âmbito do Colegiado da Autarquia eram (a) caracterização do crédito imobiliário pela origem, e não pela destinação ("critério da origem"), e (b) a contemporaneidade obrigatória do crédito, para fins de securitização. 


\subsection{Processo Administrativo CVM no 2012/12177 - Diretor Relator Roberto Tadeu Antunes Fernandes. Julgamento em 13.06.2013. (“Caso Rede D'Or)}

\subsubsection{A descrição do caso}

O julgamento do Caso Rede D’Or foi o responsável por impactar substancialmente o entendimento do Colegiado acerca do conceito de crédito imobiliário.

Como não poderia deixar de ser, o processo consistiu em mais um pedido de registro de CRI endereçado à SRE. Dessa vez, a Rede D'Or São Luís S.A. ("RD São Luís") - uma das companhias do grupo hospitalar pretendia realizar uma emissão de debêntures simples, não conversíveis em ações e com garantia flutuante, com o objetivo de captar recursos destinados à aquisição de terrenos, edificação e expansão de prédios hospitalares especificados na respectiva escritura. Na sequência, o BTG Pactual S.A. ("BTG") subscreveria e integralizaria a totalidade de tais debêntures e utilizaria o direito de crédito adquirido em face da RD São Luís para a emissão de uma CCI, a qual, após ser cedida à Brazilian Securities Companhia de Securitização ("Brazilian Securities"), serviria de lastro para a emissão de uma série de CRIs. Nas próprias palavras da Brazilian Securities, quando da realização do pedido, "os créditos que servirão de lastro para a Emissão dos CRI em questão se originam de um tradicional financiamento à construção, o que poderia ser formalizado por diversos instrumentos jurídicos existentes no ordenamento jurídico vigente, inclusive por meio de Debêntures...". Como a documentação disponível ${ }^{35}$ não informa quais ativos constituiriam a garantia flutuante das debêntures, não foi possível averiguar se a operação contaria, ou não, com a existência garantias reais.

\footnotetext{
${ }^{35}$ MEMO/SER/GER-1/N $15 / 2013$ e Ata da Sessão de Julgamento do Colegiado realizada em 13.06.2013.
} 


\subsubsection{A mudança do entendimento da área técnica e a utilização do implícita do critério da destinação}

Muito surpreendentemente, a SRE emitiu parecer favorável à estrutura da operação apresentada, afirmando, de forma peremptória, que as debêntures a serem emitidas pela RD São Luís se enquadrariam no conceito de crédito imobiliário em cumprimento à legislação vigente. Na visão da Superintendência, o fato de o objeto social da entidade hospitalar não ser relacionado à exploração de imóveis não impediria que esta pudesse realizar, mediante a emissão de debêntures, uma operação de financiamento imobiliário. Veja-se a fundamentação construída no parecer exarado:

\footnotetext{
Entretanto, afastamos essa possibilidade, pois na operação em tela, a Devedora, apesar de não ter como objeto social a exploração (com venda ou aluguel, por exemplo) dos imóveis que pretende adquirir, edificar ou expandir, utiliza-se de fato de financiamento imobiliário, ao emitir as Debêntures que serão subscritas pelo Coordenador Líder (o originador do crédito), com essa finalidade específica, consoante formalizada na Escritura das Debêntures.
}

Nesse contexto, é possível notar uma mudança radical e inesperada no entendimento da área técnica, que, diferentemente do que ocorreu em todos os outros casos citados, neste entendeu ser possível a caracterização do crédito imobiliário pela sua destinação, tão somente pelo fato de os recursos adquiridos com a emissão das debêntures serem destinados a determinada atividade imobiliária. No caso CIBRASEC, por exemplo, tanto a SRE quanto o Colegiado indeferiram o registro dos CRIs por entenderem que o fluxo de recebíveis não possuía origem real, sendo irrelevante, em absoluto, que os recursos obtidos com aquela operação fossem destinados a investimentos em bens imóveis.

Por essa lógica, a operação pretendida pela Rede D’Or jamais poderia ter sido deferida, uma vez que, na operação apresentada pelo grupo hospitalar, o crédito decorrente da emissão de debêntures não se originou de 
bem imóvel. Da mesma forma, até onde foi possível apurar, as debêntures emitidas não estavam garantidas por bens de natureza real.

Apesar de não ter reconhecido, expressamente, uma mudança de seu entendimento institucional, fato é que a SRE deferiu o pedido da Rede D'Or e autorizou o registro dos CRIs. Em seu parecer, a Superintendência afastou qualquer possibilidade de analogia entre o caso em comento e a operação prevista no Caso CIBRASEC, fundamentando que, naquele processo, os requerentes teriam buscado a emissão dos CRIs com lastro em fluxo de recebíveis decorrente da atividade econômica da companhia energética, e não em créditos oriundos de uma dívida contraída junto a terceiros. Ou seja, na visão da área técnica, os julgamentos aparentemente contraditórios se justificariam por uma suposta diferença entre as duas operações apresentadas.

De todo modo, é forçoso reconhecer que ambas as operações expressam hipóteses equivalentes na essência, na medida em que preveem, igualmente, a emissão de CRIs com lastro em créditos que não possuem origem em bem imóvel. De um lado, têm-se os créditos decorrentes de contratos de compra e venda relativos à comercialização de energia elétrica; de outro, tem-se a dívida gerada entre um terceiro e uma companhia em virtude da subscrição de debêntures por ela emitida.

Nesse sentido, não parece fazer sentido a alegação da área técnica de que o fluxo de recebíveis do Caso CIBRASEC seria meramente derivado da atividade econômica da companhia energética, e não de créditos oriundos de uma dívida contraída junto a terceiros. Ora, o que seriam os contratos de compra e venda de energia elétrica senão dívidas contraídas junto a terceiros? Com toda a vênia devida à D. Superintendência, os dois casos não parecem envolver situações essencialmente distintas. 


\subsubsection{A chegada do processo ao Colegiado e o surgimento de um novo critério: o do fluxo de pagamento}

O Colegiado se reuniu, pouco tempo depois, e discordou unanimemente da manifestação da SRE quanto à admissibilidade da operação apresentada, sustentando que "o fluxo de pagamento da operação proposta não estaria relacionado aos imóveis, mas ao fluxo de caixa da Devedora, o que não permitiria a caracterização dos recebíveis como sendo de natureza imobiliária" ${ }^{\text {,36. }}$.

Em outras palavras, o Colegiado entendeu que o crédito somente poderia ser qualificado como imobiliário se os recursos utilizados pelo devedor, no pagamento da dívida, estivessem relacionados aos imóveis envolvidos na operação. No caso do financiamento imobiliário da Rede D’Or, seria indispensável, portanto, que o capital utilizado pela RD São Luís para o pagamento de suas debêntures estivesse vinculado a bens de natureza real, o que, diante do caso concreto, não se verificou.

Ao que tudo indica, os recursos utilizados pelo RD São Luís derivariam de fontes diversas e alheias a imóveis, tais como o seu fluxo de caixa ou o seu próprio patrimônio líquido, ambos derivados de uma atividade econômico-empresarial que não era especificamente relacionada ao setor imobiliário. Muito provavelmente, o pagamento dos créditos aos debenturistas teria origem na atividade médica da rede hospitais, e não de qualquer atividade relacionada à exploração imobiliária.

\subsubsection{E o critério da origem?}

Embora tenha estabelecido um novo critério e o tenha utilizado para julgar o processo em análise, observa-se que o Colegiado se omitiu quanto ao fato de as debêntures emitidas pela RD São Luís não terem origem em

\footnotetext{
${ }^{36}$ Ata da Reunião do Colegiado da CVM n ${ }^{\circ}$ 12, de 26.03.2013.
} 
bem imóvel, contrariando, de forma implícita, a máxima de que “o crédito imobiliário se caracteriza pela origem, e não pela destinação”, a qual vinha sido reiteradamente aplicada nos precedentes anteriores da Autarquia. Da mesma forma, o Colegiado também se omitiu quanto à alegação da SRE de que, para fins de constituição de um crédito imobiliário, não seria necessário que o objeto social da devedora fosse relacionado ao setor imobiliário e de construção civil.

Com efeito, parece incompatível afirmar que o caráter imobiliário deve se verificar na origem e, ao mesmo tempo, admitir que uma debênture emitida por uma companhia possa atender a esse critério. Uma debênture não se origina ou decorre da exploração de um imóvel. Como já se teve a oportunidade de argumentar acima, a operação proposta pela RD São Luís claramente caracterizou o crédito imobiliário a partir da sua destinação.

Diante da omissão do Colegiado quanto a esse fato - o que viria a se repetir no âmbito do Processo Administrativo CVM no 19957.000587/201651, julgado em 16.08.2016 ${ }^{37}$-, é possível concluir que, ao menos implicitamente, o Colegiado da CVM deixou de lado o antigo critério da origem e passou a admitir a destinação como critério válido para a caracterização dos créditos imobiliários. Além disso, a análise dos memorandos elaborados pela SRE, nesses dois processos, indica que o entendimento da área técnica vinha sofrendo grandes alterações, de modo a admitir, de forma pacífica, a emissão de CRIs com lastro em créditos imobiliários caracterizados em sua destinação. ${ }^{38}$

\footnotetext{
${ }^{37}$ Tal como ocorreu no Caso Rede D'Or, esse processo administrativo também envolveu a emissão de CRIs com lastro em debêntures. Nessa oportunidade, a SRE chegou a reconhecer, expressamente, a existência de crédito imobiliário caracterizado na destinação (nota de rodapé 38 abaixo), tendo o Colegiado se omitido quanto a esse aspecto e se limitado a acompanhar o entendimento da área técnica quanto ao pedido principal dos requerentes. Como a companhia emissora atuava no setor imobiliário, a questão relativa ao objeto social da devedora dos créditos acabou não sendo objeto de discussão.

38 Vejam-se as assertivas da SRE no âmbito do Processo Administrativo CVM no 19957.000587/201651: “Ademais, propomos que nas emissões de CRI cujo lastro seja constituído por créditos imobiliários na sua destinação, como ocorre na presente Oferta, o efetivo direcionamento dos recursos a imóveis, de modo a configurar o vinculo previsto pelo inciso I do art. $8^{\circ}$ da Lei $n^{\circ} 9.514197$, deva ocorrer até a data de vencimento dos CRI, tendo em vista ser até
} 
Dessa forma, é possível afirmar que a decisão proferida no Caso Rede D’Or deu início a um período de transição de entendimento no âmbito da Autarquia, mudança que viria a ser consolidada, conforme se verá a seguir, no âmbito do Caso RB Capital.

\subsubsection{A conclusão do caso}

Independentemente das questões relativas ao mérito, a resolução desse caso foi pouco convencional. Após interpor um pedido de reconsideração da decisão proferida pelo Colegiado ${ }^{39}$, a Brazilian Securities desistiu da realização da operação, alegando “questões estratégicas de negócios da Devedora” e requerendo o encerramento do processo. Apesar disso, é evidente que o entendimento exposto na decisão do Colegiado deve ser levado em consideração, especialmente por ter trazido à tona um novo requisito - o do fluxo de pagamento do crédito imobiliário - e por ter admitido, implicitamente, a utilização do critério da destinação.

essa data que perdura as obrigações atribuídas ao agente fiduciário dos referidos títulos, quem deverá verificar se o referido direcionamento ocorreu conforme previsto na documentação da Oferta." (Memorando no 84/2016-CVM/SRE/GER-1)

39 No âmbito desse pedido de reconsideração, o Colegiado formulou consulta formal à PFE, solicitando, por meio desta, o parecer da Procuradoria a respeito dos temas envolvidos no processo. Em resposta, a PFE se manifestou pela manutenção do indeferimento proferido pelo Colegiado, ponderando que “... a PFE entende plenamente pertinente que o Colegiado, se assim entender necessário, estabeleça outros requisitos que tragam maior proteção ao investidor - em especial por vincular, de forma mais clara (se assim concluir), o crédito aos imóveis que serão objeto de aquisição ou construção.". 


\subsection{Processo Administrativo CVM no 19957.009618/2016-30 - Presidente Relator Leonardo Porciúncula Gomes Pereira. Julgamento em 26.06.2017. (“Caso RB Capital”)}

\subsubsection{Descrição do caso}

Tendo sido julgado apenas há alguns meses, durante a confecção do presente trabalho, o Caso RB Capital foi o responsável por reafirmar e consolidar o entendimento atual da CVM a respeito do conceito de crédito imobiliário, em especial no que toca à sua utilização no mercado de securitização e à sua adequação à disciplina da Lei 9.514/1997.

No caso concreto, a imobiliária BR Properties S.A. (" $\underline{B R}$ Properties”) emitiu uma série de debêntures com cláusula de repactuação ${ }^{40}$, as quais foram subscritas, posteriormente, por nove fundos de investimento ("Debenturistas"). Caso algum dos fundos de investimento não concordasse com as novas condições das debêntures - e recusasse, portanto, a repactuação, prevista para o prazo máximo de 180 dias -, a BR Properties recompraria os títulos desse debenturista e os cederia à RB Capital Companhia de Securitização ("RB Capital"), que, na qualidade de instituição securitizadora, utilizaria as debêntures como lastro para a emissão de uma série de CRIs.

Ainda no escopo da referida operação, os recursos obtidos pela BR Properties com a emissão das debêntures foram imediatamente utilizados para a aquisição de um imóvel pertencente ao Ventura II-A - Fundo de

\footnotetext{
${ }^{40}$ De acordo com a cartilha "O que são debêntures", elaborada pela ANDIMA e pela ABRASCA, a cláusula de repactuação é "...um mecanismo utilizado pelas companhias emissoras de debêntures - quando previsto na escritura de emissão - para adequar seus títulos, periodicamente, às condições vigentes no mercado. Na repactuação, a emissora está obrigada a recomprar os titulos dos debenturistas que não aceitarem as novas condições propostas". (ASSOCIAÇÃO NACIONAL DAS INSTITUIÇÕES DO MERCADO FINANCEIRO; ASSOCIAÇÃO BRASILEIRA DAS COMPANHIAS ABERTAS. O Que São Debêntures. Disponível em: < http://www.debentures.com.br/downloads/textostecnicos/cartilha_debentures.pdf.>. Acesso em 06.11.2017).
} 
Investimento Imobiliário FII ("Fundo Ventura"), cujo único cotista, na ocasião, era a própria BR Properties. Foi somente após a conclusão da compra e venda desse imóvel que a RB Capital endereçou o pedido de registro dos CRIs à SRE.

Por razões muito semelhantes às que viriam a ser invocadas pelo Colegiado, a SRE, apoiada em parecer exarado pela PFE-CVM, indeferiu o pleito da companhia securitizadora. ${ }^{41}$ Quando o processo chegou ao Colegiado, o então Presidente Leonardo Pereira aproveitou o caso concreto para expor o seu entendimento - que viria a ser acompanhado pelos demais membros do Colegiado, por unanimidade - do que poderia ser considerado um crédito imobiliário apto a lastrear os títulos disciplinados pela Lei 9.514/1997.

\subsubsection{A decisão do Colegiado}

Nesse sentido, a primeira e mais importante postura assumida pelo Diretor Presidente foi sanar a obscuridade das últimas decisões do Colegiado e admitir, expressamente, a possibilidade de se caracterizar o crédito imobiliário pela sua destinação. Como visto na análise do precedente acima, tal posicionamento já vinha sendo implicitamente adotado pela Autarquia desde 2013, por ocasião do julgamento do Caso Rede D'Or.

Nesse novo precedente, porém, o Diretor Presidente fez uma distinção expressa entre os créditos imobiliários tradicionais, entendidos

\footnotetext{
${ }^{41}$ Para fundamentar a sua decisão, a SRE alegou, em síntese, que (a) os recursos obtidos com a emissão das debêntures já haviam sido utilizados anteriormente à emissão dos CRI, o que inviabilizaria a oferta, e (b) a estrutura exposta não estava de acordo com a finalidade da Lei 9.514/1997, uma vez os recursos obtidos foram aplicados para a aquisição de um imóvel que, indiretamente, já pertencia à própria emissora das debêntures. O parecer da PFE, por sua vez, repisou o fato de a BR Properties já ser a proprietária do imóvel e defendeu que, para um crédito ser considerado imobiliário pela destinação, seria imprescindível que a dívida "tenha sido contraída para o desenvolvimento do mercado imobiliário brasileiro e seu pagamento seja efetuado com recursos decorrentes da exploração do objeto social de empresa no setor imobiliário".
} 
como aqueles identificados em sua origem, e as chamadas "dívidas corporativas", que seriam os créditos imobiliários caracterizados pela sua destinação. Vejam-se, a esse respeito, as palavras cristalinas do Presidente:

16. Acompanhando o entendimento da SRE, o Colegiado anuiu com a possibilidade de emissão de CRI cujo lastro fosse constituído por créditos imobiliários na sua destinação (as chamadas dívidas corporativas), e não apenas os créditos imobiliários tradicionais (que se originam de financiamento imobiliário ou da compra e venda de um imóvel). As decisões também consideraram que as devedoras das debêntures atuavam no setor imobiliário, de modo que o fluxo de pagamentos do CRI seria resultante de atividades desempenhadas no setor.

17. Portanto, não há dúvidas de que, atualmente, a posição prevalecente é a de que não apenas os créditos imobiliários tradicionais, mas também as dívidas corporativas são passíveis de lastrear a emissão de um CRI.

Embora tenha reconhecido a existência das dívidas corporativas como possível lastro de um CRI, o Diretor Presidente ressaltou que tal modalidade somente será possível quando os recursos obtidos forem efetivamente destinados a atividades do setor imobiliário, em cumprimento à essência e aos objetivos dispostos pela Lei 9.514/1997. Além disso, conforme consta do parágrafo 16 transcrito acima, seria relevante que a devedora atuasse no mercado imobiliário, de modo que o fluxo de pagamento dos CRIs - e, em última análise, das debêntures - derivasse de atividade desempenhada nesse setor.

Sobre esse ponto, veja-se, novamente, o que consta do voto do Diretor Presidente:

24. E, como se pode observar da jurisprudência da CVM desenhada ao longo do tempo, no CRI por destinação, os recursos arrecadados com a dívida corporativa devem ser empregados pela devedora em atividade legítima relacionada ao mercado imobiliário, previamente indicada nos documentos da oferta.

25. Nesse contexto, portanto, a emissão pública de CRI não pode representar mera operação de capitalização da empresa devedora, o que desvirtuaria a essência da Lei 9.514, mas sim estar vinculada ao efetivo financiamento de um projeto imobiliário. 
Tendo em vista esse raciocínio, o Colegiado acompanhou a decisão proferida pela SRE e manteve o indeferimento do pedido de registro realizado pela RB Capital. Como fundamento, o Diretor Presidente argumentou que o Fundo Ventura foi liquidado imediatamente após a aquisição do imóvel por parte da BR Properties, de modo que, ao fim e ao cabo, os recursos retornaram ao caixa da companhia - única cotista do Fundo Ventura - sem que tivesse havido qualquer destinação a projeto imobiliário específico.

Dessa forma, o Presidente concluiu que, muito embora a emissão de debêntures possa representar uma legítima dívida corporativa para os efeitos da Lei 9.514/1997, a operação estruturada pela BR Properties e pela RB Capital era, in casu, desprovida de substância econômica, sendo impossível utilizar os recursos obtidos como lastro de um CRI. Afinal, como mencionado em seu voto, a emissão de um CRI não pode ser uma mera capitalização da empresa devedora, mas deve estar atrelada, sempre, aos objetivos emanados pela Lei 9.514/1997.

\subsubsection{Conclusão}

Tendo em vista o exposto acima, é possível concluir que a decisão do Caso RB Capital esclareceu a maior parte das obscuridades existentes acerca do conceito de crédito imobiliário, consolidando, de forma mais clara, o entendimento atual do Colegiado da Autarquia.

De acordo com o novo entendimento, faz-se possível a constituição de créditos imobiliários tanto pela sua origem quanto pela sua destinação, desde que atendidos, no segundo caso, os seguintes requisitos: (a) os recursos obtidos com a constituição da dívida sejam efetivamente destinados a atividades imobiliárias e (b) o fluxo de pagamento do crédito esteja relacionado a atividades de caráter imobiliário, o que se verifica, com maior clareza, quando a devedora atua especificamente nesse setor. 
Esse segundo requisito, vale dizer, também se aplica aos créditos imobiliários caracterizados na origem, conforme explicitado na decisão do Caso Rede D'Or.

\subsection{Conclusão quanto ao entendimento atual do Colegiado}

Diante de todos os precedentes analisados, faz-se pertinente elencar, para fins didáticos, o conjunto cumulativo de critérios e premissas que devem ser obrigatoriamente observados para que um crédito possa ser considerado imobiliário, aos olhos do Colegiado da CVM, de acordo com o seu entendimento atual. São eles:

1) O crédito imobiliário pode ser caracterizado tanto pela sua origem (créditos imobiliários tradicionais) quanto pela sua destinação (dívidas corporativas);

2) Os recursos utilizados para o pagamento do crédito, pelo devedor, devem estar vinculados a bens imóveis, sendo um bom indicativo do cumprimento desse critério o fato de o devedor atuar especificamente no setor imobiliário; e

3) No caso das dívidas corporativas, além da atenção aos demais requisitos, exige-se que os recursos obtidos com a constituição da dívida sejam destinados a atividades de financiamento imobiliário;

4) Para fins de securitização, o crédito imobiliário deve ser contemporâneo, isto é, não pode dizer respeito a projeções de recebíveis, mas tão somente a créditos já constituídos.

A despeito da convicção existente em relação aos requisitos acima, há um ponto específico que restou obscuro pela análise das decisões, não sendo possível determinar, com clareza, qual seria o posicionamento da 
CVM a seu respeito: seria possível, afinal, caracterizar um crédito imobiliário pela existência de uma garantia real?

Embora o Colegiado não tenha deixado muito claro o seu posicionamento, é possível concluir que não. Afinal, imagine-se um crédito qualquer - originado por um contrato de mútuo, por exemplo - que não tenha relação com bem imóvel, mas que possua garantia real. Esse crédito não se adequaria a nenhuma das duas modalidades apresentadas no julgamento do Caso RB Capital, uma vez que não possuiria origem em um imóvel e não seria destinado, ao menos a priori, a qualquer atividade relacionada ao setor imobiliário.

Dessa forma, por mais que o Colegiado não tenha se manifestado expressamente a respeito, é possível concluir que a mera existência de garantia real não é capaz de caracterizar, por si só, um crédito como imobiliário. 


\section{Uma análise crítica do posicionamento atual da CVM e a proposta de uma interpretação diversa.}

A Comissão de Valores Mobiliários é uma das mais importantes instituições deste país, exercendo, com excelência, há mais de 40 anos, a árdua e nobre tarefa de promover a regulação do mercado de capitais brasileiro. Desde 1976, a sua atuação é marcada pelo elevadíssimo nível técnico e profissional de seus funcionários e colaboradores, dentre os quais se destacam, inexoravelmente, os ilustres profissionais que integraram (e integram) o órgão colegiado da Autarquia ao longo de todos esses anos.

Como praticamente tudo no mundo do Direito, nem mesmo as decisões desse seleto grupo de profissionais estão imunes a críticas e questionamentos. A despeito do inegável embasamento técnico que detém a Autarquia, as decisões envolvendo o conceito de crédito imobiliário vêm se destacando por apresentarem um considerável grau de obscuridade e insegurança, sendo inegável a dificuldade dos regulados - e até mesmo dos próprios reguladores, em alguns casos - de compreender qual seria o real entendimento da CVM a respeito do tema.

Além dessa dificuldade primária, alguns aspectos relativos ao mérito das decisões vêm sendo debatidos por parte da doutrina e pelos participantes do mercado. Serão expostas, neste trabalho, algumas dessas críticas e questionamentos, todos tendo como base os requisitos atuais de caracterização do crédito imobiliário elencados no capítulo 3.7 acima.

\subsection{Os aspectos positivos do entendimento atual da Autarquia}

Por questões de justiça e rigor, não seria correto dar início à presente análise crítica sem reconhecer, abertamente, os importantes acertos e avanços trazidos pelo Colegiado da CVM em suas últimas decisões sobre o tema em análise. Adequando-se cada vez mais à realidade do mercado, a 
Autarquia se aproximou da essência da Lei 9.514/1997 e promoveu, de maneira bastante sensata, um importante e necessário aprimoramento técnico na forma de disciplinar o conceito de crédito imobiliário. Trata-se, como já mencionado, de evolução bastante positiva.

Como também já se teve a oportunidade de mencionar, inclusive nas palavras de grandes doutrinadores, a Lei 9.514/1997 foi criada em meio a um grande projeto de crescimento econômico e social do país, tendo o objetivo claro e manifesto de proporcionar a expansão do mercado imobiliário brasileiro e do chamado Sistema de Financiamento Imobiliário ("SFI") ${ }^{42}$. Sob esse aspecto, é possível observar que a referida lei tem a função precípua de impulsionar o mercado imobiliário e atender, por meio da livre circulação dos créditos, às demandas daqueles que necessitam do acesso a imóveis, seja para fins habitacionais, seja para diversas outras finalidades relacionadas a esse tipo de bem.

Além disso, é interessante notar que a lei não impôs limitações à consecução de tais finalidades, e muito pelo contrário: todo o seu teor é aberto e transmite um alto grau de liberdade para a elaboração de operações que, de fato, representem um financiamento imobiliário, independentemente do aspecto da operação em que isso venha a se concretizar. Veja-se o que sustenta a própria Exposição de Motivos da referida lei:

15. O funding primário para essas operações consistirá de recursos que as entidades mencionadas captam no mercado financeiro e de valores mobiliários, mediante instrumentos próprios, dentre os quais se incluem letras hipotecárias e debêntures. Essas entidades poderão realizar financiamentos imobiliários em geral, segundo condições de mercado, utilizando, para tanto, as modalidades contratuais já tipificadas no ordenamento civil e comercial.

\footnotetext{
42 Conforme consta da sua exposição de motivos, a Lei 9.415/1997 “orienta-se segundo as diretrizes de desregulamentação da economia e modernização dos instrumentos e mecanismos de financiamento à atividade produtiva. Seu objetivo fundamental é estabelecer as condições mínimas necessárias ao desenvolvimento de um mercado de financiamento imobiliário. para o que se criam novos instrumentos e mecanismos que possibilitam a livre operação do crédito para o setor e a mobilização dos capitais necessários à sua dinamização.”.
} 
16. As operacões de financiamento serão livremente contratadas entre as partes e deverão apenas observar as seguintes condições mínimas: reposição integral do valor emprestado, remuneração do capital, capitalização dos juros e contratação de seguros considerados essenciais, como aqueles que garantem a liquidação do financiamento no caso de morte ou invalidez permanente do tomador do empréstimo. (grifou-se)

Como se pode extrair dos precedentes analisados, durante muito tempo o entendimento do Colegiado caminhou em sentido contrário aos objetivos e à finalidade da Lei 9.514/1997. Ao insistir no antigo critério da origem, o que o Colegiado fez foi criar uma restrição que não existe na lei e tampouco existiu na intenção dos legisladores -, impedindo, com base nisso, que fossem concretizadas inúmeras operações de claríssimo e incontestável caráter de financiamento imobiliário, tais como mútuos para aquisição ou reforma, emissão de debêntures voltadas à implementação de projetos imobiliários ou, de forma geral, de operações diversas cujo aspecto imobiliário se identificam em seu fim.

Não parece ser essa a melhor interpretação a ser dada ao crédito imobiliário e à sua utilização no SFI. Conforme viria a ser reconhecido pelo Colegiado, no Caso RB Capital, derivar de um imóvel não é a única forma pela qual um crédito pode representar um financiamento imobiliário. No próprio decorrer deste trabalho foram observados créditos que não tiveram origem em um imóvel e representaram, no entanto, verdadeira operação de financiamento imobiliário, inclusive movimentando recursos mais volumosos se comparados a diversos outros créditos identificados em sua origem.

Por esse motivo, é bastante justo afirmar que as últimas decisões do Colegiado - com destaque para a decisão do Caso RB Capital, que consolidou o entendimento atual da Autarquia - representam um grande avanço para os interesses do mercado de capitais e de seus regulados, na medida em que reconhecem, de maneira expressa, a possibilidade de serem considerados créditos imobiliários não apenas aqueles que derivam 
diretamente de imóveis, mas, também, aqueles oriundos de dívidas contraídas para fins de financiamento imobiliário.

\subsection{O outro lado da moeda: a inadequação do critério do fluxo de pagamento.}

Se por um lado o entendimento atual da CVM representa um avanço, reduzindo as restrições para a caracterização dos créditos imobiliários, de outro é forçoso reconhecer a subsistência de alguns elementos inadequados a um conceito que atenda a todas as necessidades do setor.

Nesse sentido, a maior crítica que vem sendo feita em relação ao posicionamento atual da CVM diz respeito ao requisito do fluxo de pagamento dos créditos, mais especificamente o que diz: "Os recursos utilizados para o pagamento do crédito, pelo devedor, devem estar vinculados a bens imóveis, sendo um bom indicativo do cumprimento desse critério o fato de o devedor atuar especificamente no setor imobiliário" ${ }^{, 43}$. Como bem mencionado ao longo do Caso RB Capital, tal requisito vem sendo exigido tanto para os créditos imobiliários caracterizados na origem quanto aos créditos imobiliários caracterizados na destinação.

O que essa exigência acaba acarretando, na realidade, é que apenas as sociedades cujos objetos sejam imobiliários estão aptas a ser devedoras de um crédito imobiliário, sendo praticamente inviável que qualquer pessoa física ou sociedade com objeto social diverso possam figurar nessa condição. Afinal, é muito improvável que uma sociedade que não atue no setor imobiliário possua um fluxo de caixa vinculado a bens imóveis e, mesmo que possua, é ainda mais improvável que esse fluxo de caixa seja robusto o suficiente a ponto de pagar todo o investimento imobiliário realizado para o exercício de suas atividades. No mundo real, apenas as

\footnotetext{
${ }^{43}$ Definição extraída do Capítulo 3.7. deste trabalho.
} 
sociedades de caráter imobiliário possuirão fluxo de caixa suficiente para pagar créditos imobiliários.

Pelo mesmo motivo, a possibilidade de pessoas físicas virem a ser devedoras de créditos imobiliários chega quase a zero, sendo indispensável a observação de que tal hipótese, na prática, é bem mais comum do que se pode imaginar. ${ }^{44}$ Como é praticamente impossível que a conta bancária de uma pessoa física esteja totalmente vinculada a bens imóveis, pode-se afirmar, com certa segurança, que essa interpretação representaria um proibitivo imediato às operações de financiamento imobiliário envolvendo pessoas físicas.

A realidade é que nem sempre a pessoa jurídica e a pessoa física pagarão o crédito imobiliário com recursos atrelados a um imóvel, mas sim com os proventos de sua atividade empresária de ramo diverso (no caso das pessoas jurídicas) ou com os proventos de seu salário, de uma herança ou de um investimento (no caso das pessoas físicas). Em ambos os casos, o pagamento dos créditos serão feitos com diversos outros recursos não relacionados a qualquer bem de natureza imóvel.

Nesse sentido, é muito adequada a crítica feita pelos autores Ivo Waisberg e Herbert Morgenstern Kugler ao discorrerem sobre o Caso Rede D’Or e o critério do fluxo de pagamento:

\begin{abstract}
Salienta-se novamente que quando uma pessoa física contrai um mútuo para fins de aquisição da casa própria, mencionada pessoa física pagará o mútuo com os rendimentos decorrentes de seu emprego, ou qualquer outra atividade econômica que exerce, sendo que, no mais das vezes, essa atividade não está relacionada à residência adquirida com os recursos do mútuo. Portanto, desnatura o crédito imobiliário o fato do fluxo de recursos que serão utilizados para quitar o financiamento imobiliário não ter relação com o bem imóvel? Cremos que não.
\end{abstract}

\footnotetext{
${ }^{44}$ Apenas a título de exemplo, é bastante corriqueiro que os CRIs voltados ao financiamento de um empreendimento imobiliário - um hotel, por exemplo - sejam emitidos com lastro nos contratos de compra e venda das próprias unidades do empreendimento, os quais são devidos pelos compradores pessoas físicas. Tal proceder se torna possível, principalmente, em virtude do prazo de carência para que sejam iniciados os pagamentos aos detentores do título. Além dessa situação, um exemplo ainda mais corriqueiro seria o mútuo tomado por pessoa física, junto a instituições financeiras, com vistas a financiar a aquisição de um imóvel.
} 
Qual a diferença entre esta situação e àquela de uma empresa emitir debêntures com a finalidade de adquirir bens imóveis, o credor das debêntures representar seu crédito por meio de uma CCI, cedê-la para uma companhia securitizadora, a qual, por sua vez, emitirá CRIs com lastro na dívida da empresa emissora das debêntures? O fluxo de pagamento dos CRI em ambos os casos não deriva do imóvel.

Haveria diferença se a rede hospitalar tivesse buscado um mútuo junto a uma instituição financeira para fins de adquirir bens imóveis? Não seria mencionado mútuo também pago com recursos oriundos da consecução do objeto social da rede hospitalar, sem qualquer associação com a exploração do imóvel adquirido com os recursos do empréstimo? ${ }^{45}$

Brilhante a análise dos autores. Um crédito não deixa de representar um financiamento imobiliário - e tampouco de cumprir as finalidades da Lei 9.514/1997 - por estar sendo quitado com recursos não relacionados a imóveis. É de se ressaltar, em relação a esse ponto, que a fonte do pagamento é elemento alheio à natureza do crédito, não possuindo o condão de determinar se este possuirá (ou não) um caráter imobiliário para os efeitos da legislação aplicável.

Ao impor aos regulados esse requisito adicional, o Colegiado da CVM parece estar cometendo equívoco semelhante ao que cometeu durante alguns anos, ao inaugurar e persistir na utilização do antigo critério da origem. Tal como ocorria naquela época, o Colegiado institui uma limitação que não encontra previsão em lei, restringindo, de maneira excessiva, a captação de recursos via constituição de créditos imobiliários, em especial no que diz respeito às emissões de CRIs. Mais uma vez, a interpretação da CVM não parece estar alinhada à essência da Lei 9.514/1997 e do mercado imobiliário de maneira geral.

Assim sendo, conclui-se ser inadequada, lógica e juridicamente, a utilização do critério do fluxo de pagamento para caracterizar os créditos imobiliários, bem como ser necessário, por esses e outros motivos, que haja um aprimoramento ainda maior do conceito por parte do órgão regulador do mercado de capitais.

${ }^{45}$ WAISBERG, Ivo; KUGLER, Herbert Morgenstern. Op. cit., p. 135. 


\subsection{Ajustes pertinentes à interpretação atual do Colegiado: a propositura de um novo modelo.}

Diante de todos os fatos e ideias expostos ao longo deste trabalho, é chegado o momento de "fechar o ciclo", propondo, com base nas diversas discussões tomadas, um conjunto de requisitos considerados apropriados para uma melhor caracterização do crédito imobiliário. Não é necessário, no entanto, estender-se na argumentação; o modelo que será proposto abaixo é apenas uma conclusão lógica de tudo o que já foi minuciosamente apresentado, criticado e sugerido em todos os capítulos anteriores, em especial no decorrer do presente capítulo 4.

Objetivamente, o modelo proposto consiste em uma versão modificada e adaptada do atual entendimento da CVM, excluindo-se o critério do fluxo de pagamento (item "2" do capítulo 3.7) e mantendo-se todos os demais. Afinal, como já se teve a oportunidade de mencionar, o entendimento da CVM apresenta destacada evolução nos últimos anos, podendo, com bastante justiça, ser utilizado como base e modelo para a construção de um conceito ainda mais correto. A única modificação que realmente é necessária fica por conta da exclusão do critério do fluxo de pagamento, conforme exaustivamente justificado no subcapítulo 4.2. acima.

Dessa forma, fica proposto, pelo presente trabalho, o seguinte conjunto de regras a ser observado na caracterização de um crédito imobiliário:

1) O crédito imobiliário pode ser caracterizado tanto pela sua origem (créditos imobiliários tradicionais) quanto pela sua destinação (dívidas corporativas);

2) No caso das dívidas corporativas, além da atenção aos demais requisitos, exige-se que os recursos obtidos com a constituição da dívida sejam destinados a atividades de financiamento imobiliário; 
3) Não é necessário que o pagamento do crédito esteja vinculado, de alguma forma, a um bem imóvel;

4) Para fins de securitização, o crédito imobiliário deve ser contemporâneo, isto é, não pode dizer respeito a projeções de recebíveis, mas tão somente a créditos já constituídos; e

5) A existência de garantia real, por si só, não é elemento válido para caracterizar um crédito como imobiliário. 


\section{Conclusão}

Conforme já foi ressaltado em algumas ocasiões, desde o capítulo introdutório, a construção de uma tese jurídica inovadora sempre foi o objetivo final e mais relevante do presente trabalho. Para alcançá-lo, foi indispensável realizar todo um trabalho de preparação do terreno, conduzindo o raciocínio desde os pilares mais básicos até as situações mais complexas e desafiadoras do nosso "mundo real".

Tendo em vista essa metodologia, a primeira parte do trabalho não poderia deixar de passar pela aceitação e demonstração de um grande problema: a legislação brasileira não definiu o que seria um crédito imobiliário. Da mesma forma, os poucos doutrinadores que se dedicaram ao tema não deram qualquer sinal de que tenham chegado a um consenso, apresentando, a despeito do altíssimo nível jurídico e intelectual de cada um deles, uma série de teses distintas e até mesmo inconciliáveis sob o ponto de vista lógico e conceitual. Observou-se, desde logo, não apenas a complexidade da questão colocada, mas, principalmente, a grande relevância de enfrenta-la e de buscar uma solução para a controvérsia.

Diante desse cenário, foi fundamental seguir em frente e compreender qual seria o posicionamento dos órgãos reguladores a respeito do tema. Ao assumir essa tarefa, constatou-se que a CVM foi o único órgão regulador que se debruçou sobre a discussão do conceito, razão pela qual se deu início a uma análise exclusiva dos precedentes fixados pela Autarquia no decorrer dos anos. Diversamente do que ocorreu na legislação e na doutrina, a análise desses precedentes demonstrou que a CVM possui, sim, um posicionamento claro e pacífico do que seria um crédito imobiliário, fazendo com que o entendimento da Autarquia se consolidasse como a maior e mais importante fonte jurídica a ser considerada para os fins do presente trabalho. 
Afinal, é preciso ser honesto: no final das contas, é o entendimento da CVM o que realmente importa para a vida dos que operam e participam do mercado. No "mundo real", é a CVM quem vai dizer se uma determinada operação poderá, ou não, ser realizada de acordo com a disciplina dos créditos imobiliários. Muitas vezes, um determinado entendimento da Autarquia é capaz de inviabilizar toda uma operação de crédito estruturada, impedindo, com isso, a consecução dos mais diversos projetos responsáveis pela movimentação da economia nacional.

É justamente por isso que existe um grande cuidado e até mesmo certa preocupação quanto aos requisitos adotados pela CVM, mais especificamente quanto à sua eventual inadequação às finalidades do mercado imobiliário. Nesse sentido, observou-se que, embora possua diversos pontos positivos - muitos deles repisados ao longo do Capítulo 4 -, o entendimento atual da Autarquia ainda apresenta algumas inconsistências e imperfeições, o que acaba abrindo, naturalmente, um espaço para pontuais e necessários aprimoramentos do conceito. Como visto acima, o principal motivo para tanto é a inadequação do critério do fluxo de pagamento, o qual vem sendo aplicado em dissonância com os objetivos do mercado e, em especial, com os objetivos da Lei 9.514/1997, que não impôs esse tipo de restrição para o desenvolvimento do setor imobiliário brasileiro.

Dessa forma, a tese jurídica exposta no presente trabalho utiliza o entendimento atual da CVM como base e retira o indevido critério do fluxo de pagamento, permitindo que outros agentes que não as sociedades atuantes no setor imobiliário também possam realizar atividades de financiamento imobiliário, como de fato realizam. Significa dizer, basicamente, que o financiamento imobiliário não é atividade privativa das sociedades atuantes no setor imobiliário, mas sim de qualquer sociedade ou pessoa que efetivamente invista em um projeto imobiliário específico.

Com isso, encerra-se o presente trabalho com a percepção de que este cumpriu, de forma satisfatória, as metas e objetivos fixados no capítulo 
introdutório, atravessando-se um percurso geral acerca do crédito imobiliário e culminando na proposta de uma nova e clara conceituação. 


\section{Bibliografia}

- RIOS JUNIOR, Arthur. Securitização de Créditos Imobiliários. Revista Magister de Direito Empresarial. Porto Alegre, v. 8, no 44, p. 75-95, abr./maio, 2012.

- ASSOCIAÇÃO BRASILEIRA DAS ENTIDADES DOS MERCADOS FINANCEIRO E DE CAPITAIS. CRI: Consolidado Mensal (N). Disponível em: <http://www.anbima.com.br/pt_br/informar/estatisticas/mercado-decapitais/cri-consolidado-mensal-n.htm>. Acesso em 06.07.2017.

- CENTRAL DE CUSTÓDIA E DE LIQUIDAÇÃO FINANCEIRA DE TÍTULOS - CETIP. CRI - Certificado de Recebíveis Imobiliários: estoque. Disponível em: <http://estatisticas.cetip.com.br/astec/series_v05/paginas/web_v04_10_03_ consulta.asp>. Acesso em 06.07.2017.

- MAMEDE, Gladston. Letra de Crédito Imobiliário e Cédula de Crédito Imobiliário Segundo a Lei 10.931, de 02 de Agosto de 2004. Revista Magister de Direito Empresarial, Concorrencial e do Consumidor, Porto Alegre, $\mathrm{n}^{\circ}$ 01, p. 47-63, fev./mar., 2005.

- FERNANDES, Jean Carlos: A definição de títulos de crédito e a readequação de seus princípios na contemporaneidade. Disponível em: $<$ http://www.cartaforense.com.br/conteudo/artigos/a-definicao-de-titulosde-credito--e-a-readequacao-de-seus-principios--na contemporaneidade/10162>. Acesso em 04.11.2017.

- SECURITIZATION STANDING COMITEE; SANBACK, Annika. Desmystifying Securitization for Unsecured Investors. Disponível em: < https://www.moodys.com/sites/products/AboutMoodysRatingsAttachments /2001700000415918.pdf.>. Acesso em 06.11.2017

- CHALHUB, Melhim Namem. Negócio Fiduciário. 4ª edição. Rio de Janeiro: Editora Renovar, 2009. 455 p. 
- Id., Alienação Fiduciária, Incorporação Imobiliária e Mercado de Capitais: Estudos e Pareceres. $1^{\text {a }}$ Edição. Rio de Janeiro: Editora Renovar, 2012. p. 490.

- SECRETARIA DE ACOMPANHAMENTO ELETRÔNICO DO MINISTÉRIO DA FAZENDA: Letra imobiliária Garantida - LIG. Disponível em: <https://www.abecip.org.br/download?file=5-seminarioabecip-pablo-fonseca-ministerio-da-fazenda1.pdf>. Acesso em 22.10.2017).

- WAISBERG, Ivo; KUGLER, Herbert Morgenstern. O conceito de crédito imobiliário para fins de securitização imobiliária: Análise e crítica ao posicionamento atual da CVM. Revista de Direito Bancário e do Mercado de Capitais. São Paulo, v. 62, Ano 16, p. 127-139, out./dez., 2013.

- PEREIRA LIRA, Ricardo. Crédito Imobiliário e sua conceptuação. A revogação da categoria dos bens imóveis por acessão intelectual pelo Código Civil Brasileiro de 2002: consequências. As pertenças e seu regime jurídico. A securitização. Os recebíveis: Créditos Recebíveis Imobiliários (CRIs) e as Cédulas de Crédito Imobiliário (CCIs). O Continuum Imobiliário como lastro da emissão desses títulos mobiliários. Revista Forense. Belo Horizonte, v. 100, no 373, p. 205-215, maio/jun., 2004.

- ASSOCIAÇÃO NACIONAL DAS INSTITUIÇÕES DO MERCADO FINANCEIRO; ASSOCIAÇÃO BRASILEIRA DAS COMPANHIAS ABERTAS. O Que São Debêntures. Disponível em: < http://www.debentures.com.br/downloads/textostecnicos/cartilha_debenture s.pdf.>. Acesso em 06.11.2017. 


$$
\text { Pontifícia Universidade } \text { Católica }_{\text {Do Rio de Janeiro }}
$$

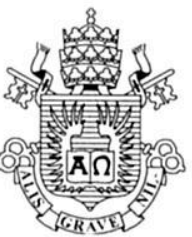

\author{
NORMAS PARA ELABORAÇÃO E APRESENTAÇÃO DA MONOGRAFIA \\ JUR 1919 ou JUR 1916
}

\title{
ANEXO II
}

\section{A Monografia deve ser entregue até o dia 08 de novembro de 2017}

A presente Monografia, apresentada pelo (a) aluno (a) Viton DE AnDnnoz SZMARAGD

poderá ser submetida à exposição e defesa perante a Banca Examinadora designada pelo Departamento de Direito da PUC-Rio.

Rio de Janeiro, 08 de nuvemsno de 2017.

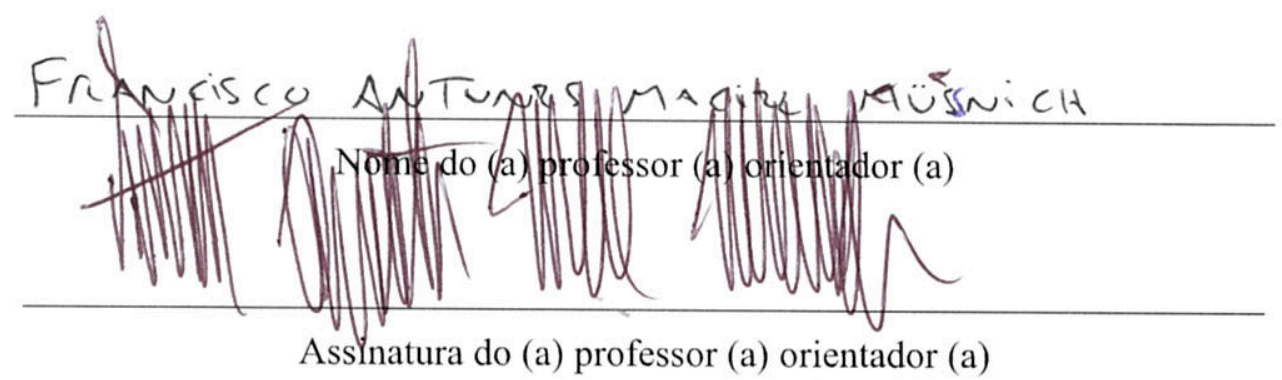

O (A) autor (a) deste trabalho declara para todos os fins de Direito ser este um trabalho inédito e autoriza o Departamento de Direito da PUC-Rio a divulgá-lo, no todo ou em parte, resguardados os direitos autorais conforme legislação vigente.

Rio de Janeiro, c8 denovengno 2017.

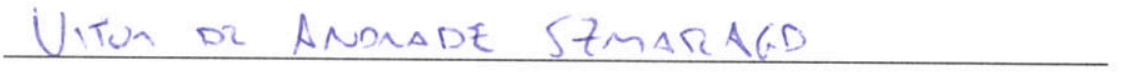

Assinatura do (a) aluno (a) 